\title{
Three-dimensional culture using a radial flow bioreactor induces matrix metalloprotease 7-mediated EMT-like process in tumor cells via TGFB1/Smad pathway
}

\author{
SHUN-ICHI SHIBATA ${ }^{1}$, HIDEKI MARUSHIMA ${ }^{1}$, TADASHI ASAKURA ${ }^{1}$, TOMOKAZU MATSUURA $^{2}$, \\ HOMARE EDA $^{1}$, KATSUHIKO AOKI ${ }^{1}$, HIROSHI MATSUDAIRA ${ }^{2}$, KAZU UEDA $^{3}$ and KIYOSHI OHKAWA ${ }^{1}$ \\ Departments of ${ }^{1}$ Biochemistry, ${ }^{2}$ Internal Medicine and ${ }^{3}$ Obstetrics and Gynecology, \\ Jikei University School of Medicine, 3-25-8, Nishi-Shinbashi, Minato-ku, Tokyo 105-8461, Japan
}

Received December 11, 2008; Accepted January 29, 2009

DOI: 10.3892/ijo_00000272

\begin{abstract}
To confirm the usefulness of the radial flow type bioreactor (RFB) for a three-dimensional (3D) culture system, which provides a tissue architecture and molecular function mimicking the in vivo environment, molecular expression in the A431 human squamous carcinoma cell line during culture were analyzed under the physically different environments of $3 \mathrm{D}$ culture in the RFB, 2D culture in a monolayer as well as in nude mice. Time-dependent accumulation of autocrine transforming growth factor (TGF) B1 was found in spent culture media obtained only from 3D cultured A431 cancer cells, which grew well with a stratified-sheet morphology. Cells in the RFB overexpressed matrix metalloproteinase 7 (MMP7) and showed an increased release of soluble $80-\mathrm{kDa}$ fragments of E-cadherin into the media time-dependently, resulting in the reduction of E-cadherin protein at the cell surface without down-regulation of the mRNA. B-Catenin and its nuclear partner, LEF1, were up-regulated and Wnt protein secretion was also accelerated. Additional up-regulation of the transcriptional factors, HMGA2 and down-stream Slug, was noted. TGF31-dependent, MMP7-mediated up-regulation of ß-catenin/LEF1 signaling and TGFß1-activated HMGA2 pathways consequently converged with Slug overexpression, due to disassembly and further repression of E-cadherin expression, which was reproducible in the epithelial mesenchymal transition process without any manipulation. Other transcriptional factors, Notch/HEY1 and NF- $\mathrm{KB}$, were also up-regulated in 3D-cultured cells. These signals recruited molecules related to extracellular matrix-cell remodeling and angiogenesis. Expression of several representative molecules in the $3 \mathrm{D}$ cultured cells was parallel with that in xenotransplanted
\end{abstract}

Correspondence to: Professor Kiyoshi Ohkawa, Department of Biochemistry, Jikei University School of Medicine, 3-25-8, Nishi-Shinbashi, Minato-ku, Tokyo 105-8461, Japan

E-mail: pko@jikei.ac.jp

Key words: matrix metalloprotease 7, transforming growth factor $\beta 1 /$ Smad
A431 tumor tissues in nude mice. 3D culture of tumor cells in the RFB is a useful tool for cancer experimental biology and evaluation of cancer therapeutic-like systems in nude mice.

\section{Introduction}

In vitro tumor growth in a three-dimensional (3D) architecture has been demonstrated to play an important role in cancer biology research (1-3) and in experiments not only on tumor expansion and metastasis $(1,4,5)$, but also on the resistance of cancers to various anticancer agents or irradiation $(6,7)$. In general, the conventional monolayer (2D) cell culture method can be used more easily for the manipulation of cells, especially genes, to investigate the genetic and biochemical changes during carcinogenesis and cancer therapy, but the induced effects can only be observed in a flat, 2D sheet of culture cells. To resolve this dilemma, a novel culture system that closely mimics the living environment in which cancer pathogenesis occurs is required $(1,2)$. Animal models yield a more accurate morphological representation of the tumor environment, but there may be unknown biological effects of the specific animal itself on the tumor cells; moreover, animal models are less amenable to large-scale studies $(2,8)$. To this end, as mentioned by Friedrich (2), a 3D cell culture system, which combines the benefits of animal models and 2D cell culture, appears to be an in vitro culture system that allows cells to develop into structures similar to those in living organisms, thereby enabling the investigation of some of the biological changes occurring after the manipulation of cancer cells. Multicellular tumor spheroids have been known to display features of drug and radiation resistance closely matching those detectable in vivo $(1-4,6,7)$.

In our laboratory, several cell lines derived from hepatocellular carcinoma culture in a radial flow type bioreactor (RFB), which is a type of 3D culture system with a high density cell population, showed not only improved cell functions, but also a differentiated morphology as compared with those grown in $2 \mathrm{D}$ culture $(5,9-11)$. A representative result demonstrating the functional effectiveness of this system was that use of the RFB system to culture functional liver cells cured a mini-pig with amanitin-, galactosamine-induced acute liver failure as it served as an artificial liver system (10). 
A key clinical turning point in cancer progression is metastasis $(8,12-14)$, which is the establishment of emigrant cells at secondary growth sites. The metastatic process comprises numerous steps; however, the critical and essential event is the acquisition by the cancer cells of the capacity to infiltrate the surrounding tissue and alter the morphology, cellular architecture, adhesion and migration capacity. The first event of the cascade is known as the epithelial-mesenchymal transition (EMT) (15-21). In cancer progression, EMT refers to clusters of malignant cells that lose their epithelial characteristics and acquire self-sustained migratory and highly matrix-invasive cell phenotypes, resulting in benign tumor cells acquiring the ability to undergo distant metastasis and develop malignant characteristics. If the features of the EMT processes can be reconstituted and maintained in a variety of biological environments under an in vitro $3 \mathrm{D}$ culture system, further development of viable cancer therapeutic approaches targeting this phenotype may result from determining the underlying molecular signaling networks of EMT (22).

The aim of this study was to clarify the characteristic gene expression that is intimately related to EMT in a squamous cell carcinoma cell line, A431, growing in the physically different environments of 3D culture in an RFB and 2D culture in a monolayer culture system and also to confirm that the RFB culture system is a useful experimental tool in the fields of cancer biology and therapeutics.

\section{Materials and methods}

Materials and reagents. A RFB system was purchased from Able Co., Inc., Tokyo, Japan. Hydroxyl apatite beads were provided by Pentax Co., Ltd., Japan. The RPMI-1640 cell culture medium was obtained from Invitrogen, Carlsbad, CA and fetal bovine serum (FBS) was sourced from SigmaAldrich, Tokyo, Japan. Recombinant human matrix metalloproteinase (MMP) 7 (matrilysin) and its inhibitor II were obtained from Merck Biosciences, Tokyo, Japan. All antibodies used were available from commercial sources. MG132 was purchased from Peptide Inst. Inc., Osaka, Japan. All other chemicals used were of analytical grade.

$2 D$ (monolayer) culture in conventional form. The human squamous cell carcinoma cell line A431, obtained from the Japanese Cancer Research Resources Bank, was routinely cultured and allowed to grow to almost $80 \%$ confluence before use in conventional monolayer culture dishes (No.664 160, Greiner Bio One, Japan) with growth media (RPMI-1640 media supplemented with $10 \%$ heat-inactivated FBS), at $37^{\circ} \mathrm{C}$ in $5 \% \mathrm{CO}_{2}$. The culture media were changed every 3 days and the respective spent culture medium was collected and stored with a protease inhibitor cocktail (\#78415, Pierce, Rockford, IL) at $-80^{\circ} \mathrm{C}$. For the confirmation of intimate association of MMP7 with soluble E-cadherin releasing, A431 cells at 80\% confluence in a 2D culture dish (No.628 160, Greiner) with $2 \mathrm{ml}$ of growth media, were treated continuously for 6 days with or without recombinant human MMP7 (20 units/dish, active form, Merck Biosciences) in the presence or absence of MMP7 inhibitor (MMP Inhibitor II, $5 \mu \mathrm{M} /$ dish, Merck Biosciences). Culture media were changed on alternate days and each group of resultant conditioned media (CM) was collected and stored at $-80^{\circ} \mathrm{C}$. The $\mathrm{CM}$ from 3 -separated periods of each group were used for the analysis of E-cadherin fragmentation.

$3 D$ culture in RFB. A 3D cell culture system using $5 \mathrm{ml}$ RFB comprises a high pore density matrix consisting of hydroxyl apatite beads with a wide surface attachment area (diameter 0.6-1.0 mm, pore size $<200 \mu \mathrm{m})(5)$. A431 cells $\left(1 \times 10^{7}\right)$ were injected into the reservoir of the RFB system, which was filled with $150 \mathrm{ml}$ of growth media circulating between the chamber and the RFB; the cells were adhered to the porous culture beads at a rate based on the medium flow. After $24 \mathrm{~h}$ from inoculation, there were no remaining cells in the chamber media. The RFB cell culture system, which included a circulation pump and the reservoir, was fully maintained in an incubator at $37^{\circ} \mathrm{C}$ in a constant atmosphere of $5 \% \mathrm{CO}_{2}$. Culturing conditions ( $\mathrm{pH}$, glucose and lactate concentrations) in the system were monitored through the experiments $(5,11)$. The culture media were changed every 3 days and the $\mathrm{CM}$ were collected and also stored with a protease inhibitor at $-80^{\circ} \mathrm{C}$. Two weeks after the inoculation, the cell culture reached approximate confluence and the hydroxyl apatite beads in the RFB were collected into $3.5-\mathrm{ml}$ cryogenic tubes (No.127 261, Greiner) to be kept in liquid nitrogen until use.

Enzyme-linked immunosorbent assay of TGFß1. TGFß1 levels in the CM were measured using Quantikine (human TGFß1, R\&D Systems, Inc., Minneapolis, MN), carried out according to the manufacturer's instructions. Briefly, the $\mathrm{CM}$ with diluents and TGFß1 standards (ranging from 31.2 to $1000 \mathrm{pg} / \mathrm{ml}$ ) were incubated overnight at $4^{\circ} \mathrm{C}$ on an anti-TGFß1 antibody-coated microtiter plate. After washing the wells, incubation was continued for $2 \mathrm{~h}$ at $37^{\circ} \mathrm{C}$ with horseradish peroxidase (HRP)-conjugated sandwich antibody against TGFß1 and then color development was performed. The absorbance was determined at $450 \mathrm{~nm}$ and the TGF 31 concentrations were calculated from the standard curve. The background level of TGFß1 in the starting media was subtracted from each sample of the CM. Data were expressed as follows:

$\%$ increase $=\left[\right.$ TGFB1 $\left(\mathrm{ng} / 10^{6}\right.$ cells in $\left.\mathrm{ml}\right)$ of spent culture medium from each period/TGFß1 in medium from initial culture] x 100

mRNA isolation and DNA microarray analysis. After culturing the cells, total RNA was extracted using the RNeasy kit (Qiagen, Tokyo, Japan) as described previously (5) and the integrity was determined using Agilent 2100 Bioanalyzer (Agilent Technologies, Waldbronn, Germany). In the case of $3 \mathrm{D}$ culture, cells adhering to the beads were gently rinsed twice with cold $10 \mathrm{mM}$ Na-phosphate buffer, $\mathrm{pH}$ 7.0, 0.15 M $\mathrm{NaCl}$ (PBS) and the whole content was used as the RNA source. For gene expression profiling, a Human Genome U133 Plus 2.0 array (Affymetrix, Santa Clara, CA) containing $>54,000$ probe sets was used. Target cRNA preparations from total RNA, hybridization to the microarray, washing and staining with the antibody amplification procedure, and scanning were all carried out according to the manufacturer's instructions. DNA microarrays were scanned and the images obtained were analyzed using the GeneChip ${ }^{\circledR}$ Operating 
Software (Affymetrix). Two separate hybridizations were performed for each sample and the average signal intensities were calculated. Raw data were collected using a confocal laser scanner, and pixel levels were analyzed using commercial software (Gene Spring Version 7, Silicon Genetics, Redwood City, CA). As the results obtained from DNA microarray analyses were labile with partially low sensitivity, several representative molecules showing significant changes in expression were picked-up and examined in further detail from the up- to down-stream directions of the pathways as described below.

Reverse transcription-polymerase chain reaction ( $R T-P C R)$ analysis. The samples used for the RT-PCR analysis were the same as those used in the cDNA microarray analyses. The procedures were carried out largely as described in a previous study (11). Briefly, extracted RNAs were reverse-transcribed using random primers and SuperScript II reverse transcriptase (Invitrogen). Semi-quantitative RT-PCR experiments were carried out with the same gene-specific primers as those prepared for construction of our cDNA microarray or with B-actin- or glyceraldehyde-3-phospate dehydrogenase (GAPDH)-specific primers as an internal control. Reactions were optimized for the number of cycles to ensure product intensity within the logarithmic phase of amplification. The following primer sequences in each gene were used (Table I).

Sodium dodecylsulfate-polyacrylamide gel electrophoresis (SDS-PAGE) and Western blot analysis. Whole cell lysates were prepared using lysis buffer $(50 \mathrm{mM}$ Tris- $\mathrm{HCl}, \mathrm{pH} 7.5$, $0.15 \mathrm{M} \mathrm{NaCl}, 1 \%$ sodium deoxycholate, $1 \mathrm{mM}$ EDTA, $1 \mathrm{mM}$ $\mathrm{Na}_{3} \mathrm{VO}_{4}, 1 \mathrm{mM} \mathrm{NaF}, 1 \%$ Triton $\left.\mathrm{X}-100\right)$ and protease inhibitor cocktail (Pierce). In the case of 3D cultures, cells adhering to the beads were rinsed twice with cold $20 \mathrm{mM}$ Tris- $\mathrm{HCl}, \mathrm{pH} 7.5$, $0.15 \mathrm{M} \mathrm{NaCl}$ (TBS) and the whole contents were lyzed for 20 min on ice using a lysis buffer. After brief sonication at $4^{\circ} \mathrm{C}$, the lysates were cleared by centrifugation at $4^{\circ} \mathrm{C}$ for $20 \mathrm{~min}$. The protein was measured by the DC protein assay kit (Bio-Rad, Hercules, CA) using bovine serum albumin (BSA) as the standard. SDS-containing and heat-denatured cell lysates were electrophoresed and the gels were transblotted to nitrocellulose filters. After blocking with 5\% BSA in $0.05 \%$ Tween-20 in TBS (T-TBS), the blots were incubated with the corresponding first antibodies followed by HRP-labeled antimouse immunoglobulin $\mathrm{G}$ (IgG) or anti-rabbit $\operatorname{IgG}$ and the signals were developed with Enhanced Chemiluminescence (Pierce). The primary antibodies used were the murine monoclonal antibodies against the human multi-ubiquitin-chain (FK2, MBL, Japan), $\alpha$-tubulin, phosphorylated (Thr183/ Tyr185) extracellular signal regulated kinase (ERK) 2 (Sigma-Aldrich), P-32, P-27 (Progen Biotecnik, Germany), hypoxia-inducible factor- $1 \alpha$ (HIF- $1 \alpha)$, vimentin, integrin $\alpha \mathrm{V}$, integrin $\alpha 5$, ZO1, plasminogen activator inhibitor-1 (PAI-1), fibronectin, p-21 ${ }^{\text {WAF1 }}$, heat shock protein 70 (BD Biosciences Pharmingen, Japan), rabbit monoclonal antibodies against human E-cadherin, Keratin 18, nuclear factor- $\mathrm{B}(\mathrm{NF}-\kappa \mathrm{B})$, Smad3, phosphorylated (Se423/425) Smad3, B-catenin, p-53, Jun N-terminal kinase kinase (SEK1/MKK4), GAPDH and phosphorylated (Se80) MKK4 (Epitomics, Burlingame, CA), rabbit polyclonal antibodies against human connexin26, furin,
CD44 (Zymed, Invitrogen), angiopoietin like-4 (CycLex, Nagoya, Japan), MMP7 (Abgent, San Diego, CA), Wnt7A (PTG Inc., Chicago, IL) and lysyl oxidase (LOX, Abcam, Tokyo, Japan).

Immunoprecipitation. For the detection of the soluble form of E-cadherin in culture media, the $\mathrm{CM}$ were immunoprecipitated with rabbit anti-human E-cadherin antibody and protein $\mathrm{G}$ plus protein A agarose beads (Merck Biosciences). The precipitates were washed 3 times with lysis buffer, mixed and boiled with SDS-electrophoresis sample buffer and subjected to SDSPAGE followed by Western blot analysis.

Densitometric analysis. Digital images of electrophoretic bands were captured by Adobe Photoshop CS software and were performed using the NIH Image J, 1.36b software.

Assay for proteasome activity. Proteasome activity in $50 \mu \mathrm{g}$ of cytosolic extracts was assayed in a $100-\mu 1$ reaction mixture containing $50 \mathrm{mM}$ HEPES, pH 7.5, $2 \mathrm{mM}$ dithiothreitol, $0.035 \%$ SDS, $10 \%$ glycerol and $100 \mu \mathrm{M}$ suc-LLVY-AMC (Sigma-Aldrich) at $37^{\circ} \mathrm{C}$ for $10 \mathrm{~min}$. Fluorescence was determined at $380 \mathrm{~nm}$ excitation/460 $\mathrm{nm}$ emission, by means of a spectro-fluorophotometer (RF-5300PC, Shimadzu, Japan).

Xenotransplantation of A431 cells to nude mice as an in vivo tumor model. A431 cells $\left(5 \times 10^{6}\right)$ were transplanted into the subcutaneous tissue of the lateral abdominal wall of male nude mice (BALB/c nu/nu, 6 weeks old, Clea, Japan) under specific pathogen-free conditions. Four weeks after transplantation, tumor tissues ( $2 \times 3 \mathrm{~mm}$ in size) were removed under general anesthesia. Both total RNA and protein were isolated from several small pieces of tumor tissue by means of the same procedures as described in the above sections. All animal studies were conducted in accordance with the principles and procedures outlined in the Guidelines on Animal Experimentation of the Jikei University.

Zymography. Enzyme activities of MMP2, -7, and -9 were analyzed as follows. CM from 2D and 3D culture were electrophoresed by SDS-PAGE containing $0.1 \%$ gelatin (Sigma-Aldrich, for MMP2 and -9) or $0.1 \%$ casein (SigmaAldrich, for MMP7) under non-reducing conditions without heating. After twice rinsing the gels with $50 \mathrm{mM}$ Tris- $\mathrm{HCl}$, $\mathrm{pH} 7.5,2.5 \%$ Triton $\mathrm{X}-100$ for $30 \mathrm{~min}$, they were incubated for $17 \mathrm{~h}$ at $37^{\circ} \mathrm{C}$ in $50 \mathrm{mM}$ Tris- $\mathrm{HCl}, \mathrm{pH} 7.5,10 \mathrm{mM} \mathrm{CaCl}_{2}$, $0.01 \mathrm{mM} \mathrm{ZnCl}_{2}, 0.15 \mathrm{M} \mathrm{NaCl}$, and $0.05 \% \mathrm{NaN}_{3}$ to allow the enzymes to digest the gelatin/casein structure. The gels were stained with Coomassie Brilliant Blue R-250 (Sigma-Aldrich) and de-stained with methanol/acetate.

Immunocytochemical observation. 2D cultures of A431 cells and human normal skin keratinocytes (KJB100, Dainippon Sumitomo Pharma, Japan) were carried out using a glass bottom culture dish (No.3911-035, Asahi Techno Glass, Japan). In RFB 3D culture, A431 cells adhering to the beads were harvested in microcentrifuge tubes. The cultured cells were gently rinsed twice with cold-TBS, fixed with $3.3 \%$ formaldehyde in TBS for $10 \mathrm{~min}$ at $4^{\circ} \mathrm{C}$, rinsed with TBS, and permeabilized with $1 \%$ Triton $\mathrm{X}-100$ in TBS for $10 \mathrm{~min}$ at 
Table I. Primers used.

\begin{tabular}{|c|c|c|c|c|}
\hline Gene symbols/gene names & Gene ontology & bp & $5^{\prime}$ & $3^{\prime}$ \\
\hline JAG1/jagged 1 VEGFA/ & Angiogenesis & 497 & agagtcagtcgggaggcaaa & cttgcagacgcacgtaaagg \\
\hline vascular endothelial growth factor A & Angiogenesis & 442 & cgaaaccatgaactttctgc & cggettgtcacatttttctt \\
\hline ANGPTL4/angiopoietin-like 4 & Cell communication & 350 & gcaggatccagcaactcttc & gcgectctgaattactgtcc \\
\hline CD44/CD44 molecule & Cell communication & 476 & ctccagcaccatttcaacca & gtcccatggggtgtgagatt \\
\hline CDH1/E-cadherin & Cell communication & 567 & ggttcaagctgctgaccttc & agccagttggcagtgtctct \\
\hline $\mathrm{CDH} 2 / \mathrm{N}$-cadherin & Cell communication & 527 & ggacagttcctgagggatca & tggtttgaccacggtgacta \\
\hline COL4A1/collagen, type IV, $\alpha 1$ & Cell communication & 469 & accctggaaacccaggactt & ttggtggcgaagtctccttt \\
\hline FN1/fibronectin 1 & Cell communication & 196 & tgttcgtgcagctgtttacc & gccaccgtaagtctgggtta \\
\hline GJA1/Connexin-43 & Cell communication & 249 & atggacagtctgectttcgt & tctgcttcaagtgcatgtcc \\
\hline GJB2/Connexin-26 & Cell communication & 415 & ccgtcctcttcatttttcgc & tgcatggagaagccgtcgta \\
\hline HMGA2/high mobility group AT-hook 2 & Cell communication & 243 & tcctcetcttgctacctcca & tcgggagatgaggtgatagg \\
\hline IL1B/interleukin $1 B$ & Cell communication & 470 & gggcctcaaggaaaagaatc & agctgactgtcctggctgat \\
\hline ITGA3/integrin, $\alpha 3$ & Cell communication & 439 & agtggctctgcctttggttt & ttcgcctgtagttggggttc \\
\hline ITGA4 /integrin, $\alpha 4$ & Cell communication & 397 & gtctggccgggattctttc & catctcttggggcgttcttc \\
\hline ITGA5/integrin, $\alpha 5$ & Cell communication & 405 & cagcctcagaaggaggagga & ctcccgctgcaagaaagtct \\
\hline ITGA6 / integrin, $\alpha 6$ & Cell communication & 440 & aacttggacactcgggagga & tetcceccatccatatcgtc \\
\hline ITGAV/integrin, $\alpha \mathrm{V}$ & Cell communication & 342 & tccetgtccatcagcatcaa & gctcccaaagcaaacaccac \\
\hline ITGB1/integrin, $B 1$ & Cell communication & 407 & tctgggctttacggaggaag & ggttgcactcacacacacga \\
\hline ITGB2/integrin, $B 2$ & Cell communication & 369 & tgagggcggaaaataactgg & tgagagccgagagtgtgtgg \\
\hline ITGB5/integrin, B 5 & Cell communication & 494 & gtgccaggaacaagggagtc & gttgggggtgtttccacact \\
\hline ITGB6 / integrin, B 6 & Cell communication & 440 & aacttggacactcgggagga & tetcccccatccatatcgtc \\
\hline LAMA3/laminin, $\alpha 3$ & Cell communication & 344 & cctcagtccatccacaacca & gctcaccacttcccaagacc \\
\hline LAMB3/laminin, B 3 & Cell communication & 314 & cagggcaaaacacaagagga & ctggagtctgggaagggatg \\
\hline LAMC2/laminin, $\gamma 2$ & Cell communication & 370 & tgaatggagggatggatgtg & agctatggtgcttgctggtg \\
\hline LOXL2/lysyl oxidase-like 2 & Cell communication & 470 & cccgagtacttccagcaacc & gctcgaatccgaatgtcctc \\
\hline PLAU/plasminogen activator, urokinase & Cell communication & 223 & tcaccaccaaaatgctgtgt & aggccattctcttccttggt \\
\hline CLDN1/claudin 1 & Cell junction & 473 & tacgaggggctgtggatgt & ggtgcaggttttggataggg \\
\hline OCLN/occludin & Cell junction & 436 & ttgccattgtactggggttc & gacettcetgctcttccettt \\
\hline TJP1/tight junction protein 1 (zona occludens 1 ) & Cell junction & 548 & gtctgccattacacggtcct & ggtctctgctggettgtttc \\
\hline IL8/interleukin 8 & Chemokine activity & 210 & gtgcagttttgccaaggagt & acttctccacaaccetctgc \\
\hline ACTA2/actin, $\alpha 2$, smooth muscle, aorta & Cytoskeleton & 368 & actgggacgacatggaaaag & gaaggaatagccacgctca \\
\hline ACTB/actin, $B$ & Cytoskeleton & 254 & aacaccccagccatgtac & atgtcacgcacgatttcc \\
\hline DSP/desmoplakin & Cytoskeleton & 351 & cagaaagcaaggcaatgtga & gctgtcattgagcctgacaa \\
\hline KRT14/keratin 14 & Cytoskeleton & 189 & ttctgaacgagatgcgtgac & gcagctcaatctccaggttc \\
\hline KRT16/keratin 16 & Cytoskeleton & 443 & tgagacctggttcctgagca & tcgaagaggacgaggaggag \\
\hline KRT18/keratin 18 & Cytoskeleton & 164 & cacagtctgctgaggttgga & gagctgctccatctgtaggg \\
\hline VIM/vimentin & Cytoskeleton & 170 & gagaactttgccgttgaagc & tccagcagcttcctgtaggt \\
\hline ID2/Inhibitor of DNA binding 2 & DNA binding & 353 & ggaattgcccaatctaagca & aaagcaggcaatcaccattc \\
\hline SLUG/snail homolog 2 & DNA binding & 161 & ctttttcttgecetcactgc & acagcagccagattcctcat \\
\hline SNAI1/snail homolog 1 & DNA binding & 415 & tttaccttccagcagcceta & ccaggctgaggtattccttg \\
\hline TWIST/twist homolog 1 & DNA binding & 468 & ctgagcaacagcgaggaag & catcttggagtccagctcgt \\
\hline LEF1/lymphoid enhancer-binding factor 1 & DNA binding & 515 & gacgagatgatccccttcaa & tcaggagctggaggatgtct \\
\hline $\begin{array}{l}\text { PLAUR/plasminogen activator, } \\
\text { urokinase receptor }\end{array}$ & Enzyme binding & 386 & ggaaggtgtcgttgttgtgg & gctggagctggtggagaaaa \\
\hline MMP2/MMP2 & Extra-cellular matrix proteins & 369 & gtgcgaccacagccaactac & tcacagtccgccaaatgaac \\
\hline MMP3/MMP3 & Extra-cellular matrix proteins & 335 & aacctgtccetccagaacct & atcgattttcctcacggttg \\
\hline MMP7/MMP7 & Extra-cellular matrix proteins & 442 & ccaaactcaaggagatgcaaa & agactgctaccatccgtcca \\
\hline МMP9/MMP9 & Extra-cellular matrix proteins & 321 & gcaccaccacaacatcacct & ccaaaccgagttggaaccac \\
\hline MMP14/MMP14 & Extra-cellular matrix proteins & 589 & gcttgcaagtaacaggcaaa & aaattctccgtgtccatcca \\
\hline FGF2/fibroblast growth factor 2 & Growth factor activity & 303 & agcggctgtactgcaaaaac & cagttcgtttcagtgccaca \\
\hline TGFA & Growth factor activity & 168 & tgtgtctgccattctgggta & gacctggcagcagtgtatca \\
\hline TGFB1/TGF $\beta 1$ & Growth factor activity & 239 & gggactatccacctgcaaga & cctccttggcgtagtagtcg \\
\hline FXYD5/Dysadherin & Ion channel activity & 428 & caccagaggacagacgttga & ggatgatgatgcctgtgatg \\
\hline $\begin{array}{l}\text { GAPDH/glyceraldehyde-3-phosphate } \\
\text { dehydrogenase }\end{array}$ & Oxidoreductase activity & 326 & catcaccatcttccaggagc & tgatggcatggactgtggtc \\
\hline LOX/lysyl oxidase & Oxidoreductase activity & 223 & cagaggagagtggetgaagg & ccaggtagctggggtttaca \\
\hline NOS2A/nitric oxide synthase $2 \mathrm{~A}$ (inducible) & Oxidoreductase activity & 313 & gcgtctgcagcacttggatc & gagtagcctgtgtgcacctg \\
\hline
\end{tabular}


Table I. Continued.

\begin{tabular}{|c|c|c|c|c|}
\hline Gene symbols/gene names & Gene ontology & bp & $5^{\prime}$ & 3 \\
\hline \multicolumn{5}{|l|}{ ADAM10/A disintegrin and } \\
\hline $\begin{array}{l}\text { ADAM15/A disintegrin and } \\
\text { metalloproteinase domain } 15\end{array}$ & Peptidase activity & 504 & gctgctaccagggaagagtg & ggaagttttcgagggtgaca \\
\hline PSEN1/presenilin 1 & Peptidase activity & 405 & ggtccacttcgtatgctggt & ggctgttgctgaggctttac \\
\hline PTGS2/cyclooxygenase-2 & Peptidase activity & 539 & gcagttgttccagacaagca & caggatacagctccacagca \\
\hline $\mathrm{CTSD} /$ cathepsin D & Protease & 174 & gacacaggcacttccetcat & ctctggggacagcttgtagc \\
\hline FURIN/furin & Protease & 463 & tgtggtgtaggtgtggecta & tgtgagactccgtgcacttc \\
\hline $\begin{array}{l}\text { PI3/peptidase inhibitor } 3 \text {, } \\
\text { skin-derived (SKALP) }\end{array}$ & Protease & 193 & agcagcttcttgatcgtggt & gacctttgactggctcttgc \\
\hline \multicolumn{5}{|l|}{ SERPINE1/Plasminogen } \\
\hline activator inhibitor 1 & Protease & 192 & ctctctctgectcaccaac & gtggagaggctcttggtctg \\
\hline TIMP1/TIMP-1 & Protease & 442 & ggggacaccagaagtcaacc & caaggtgacgggactggaa \\
\hline \multicolumn{5}{|l|}{ APH1A/anterior pharynx } \\
\hline defective 1 homolog A (C. elegans) & Protein binding & 376 & ccgctttgectactacaagc & ctcataccaggggttcagga \\
\hline \multicolumn{5}{|l|}{ APH1B/anterior pharynx defective 1} \\
\hline homolog B (C. elegans) & Protein binding & 424 & tttcgtccettgtttggttc & aggatgccccactttttctt \\
\hline DSG1/desmoglein 1 & Protein binding & 377 & aaggtgtaggttcccetgct & gggcttcagagtgtcagagg \\
\hline DSG2/desmoglein 2 & Protein binding & 385 & caccaaccactgtgatcctg & gtggtgttcctagccgtcat \\
\hline DSG3/desmoglein 3 & Protein binding & 469 & tctgttcctcagggcagtct & gaggtggacaaagcagaagc \\
\hline DSG4/desmoglein 4 & Protein binding & 339 & gtgcacccatgttcattctg & accaattcccatcatttcca \\
\hline NCSTN/nicastrin & Protein binding & 434 & caaagcacettcagcatcaa & tctgtgtgcatccaaagctc \\
\hline $\begin{array}{l}\text { PSENEN/PEN-2 } \\
\text { (Presenilin enhancer protein 2) }\end{array}$ & Protein binding & 218 & tgccttttctctggttggtc & caggggtatggtgaaggaga \\
\hline FZD10/frizzled homolog 10 (Drosophila) & Receptor activity & 462 & tgactcgtatgeccaacctg & tctccacgtggtggaacttg \\
\hline TGFBR1/TR ß I & Receptor activity & 397 & gagcatggatccetttttga & aacatcgtcgagcaatttcc \\
\hline TGFBR2/TR ß II & Receptor activity & 342 & ttttccacctgtgacaacca & gctgatgectgtcacttgaa \\
\hline WNT5A/Protein Wnt-5a & Signal transducer activity & 380 & ggaccacatgcagtacatcg & cactctcgtaggagccettg \\
\hline WNT5B/Protein Wnt-5b & Signal transducer activity & 469 & tgaacctgcaaaacaacgag & acgatctccgtgcacttctt \\
\hline WNT7A/Protein Wnt-7a & Signal transducer activity & 355 & cctggaggagaacatgaagc & acagcacatgaggtcacagc \\
\hline WNT7B/Protein Wnt-7b & Signal transducer activity & 353 & tcaacgagtgccagtaccag & ggcetcattgttatgcaggt \\
\hline FOXC2/forkhead box C2 & Transcription activating factor & 349 & cctacctgagcgagcagaat & accttgacgaagcactcgtt \\
\hline $\mathrm{CTNNB} /$ catenin $\beta 1$ & Transcription coactivator activity & 394 & cccactaatgtccagcgttt & aatccactggtgaaccaagc \\
\hline cs1/CFB1/SUH/Lag1 & Transcription factor activity & 150 & aggtaatttcatgccagttcaca & catgccagtaactgagcacaca \\
\hline CUTL1/cut-like homeobox 1 & Transcription factor activity & 488 & cagaaagcggcttatcgaac & cttcctccagctttgaggtg \\
\hline $\begin{array}{l}\text { FOS/v-fos FBJ murine osteosarcoma } \\
\text { viral oncogene homolog }\end{array}$ & Transcription factor activity & 415 & ggagaatccgaagggaaagg & gatgatgctgggaacagga \\
\hline FOSL1/FOS-like antigen 1 & Transcription factor activity & 410 & ggcggagactgacaaactgg & aagcgaggagggttggagag \\
\hline GSC/goosecoid homeobox & Transcription factor activity & 548 & gcatgttcagcatcgacaac & gtccgggtacttggtctcct \\
\hline $\begin{array}{l}\text { HEY1/hairy/enhancer-of-split related with } \\
\text { YRPW motif } 1\end{array}$ & Transcription factor activity & 417 & cgaggtggagaaggagagtg & agatgcgaaaccagtcgaac \\
\hline JUN/c-Jun & Transcription factor activity & 421 & acgcaaacctcagcaacttc & tgtttaagctgtgecacctg \\
\hline $\begin{array}{l}\text { MTA3/metastasis associated } 1 \text { family, } \\
\text { member } 3\end{array}$ & Transcription factor activity & 571 & cccgagacatcaccttgttt & ggcattttcaagcetccata \\
\hline NFкB1/nuclear factor $\kappa \mathrm{B}$ & Transcription factor activity & 425 & cacctagctgccaaagaagg & tcccaagagtcatccaggtc \\
\hline SMAD2/Smad2 & Transcription factor activity & 327 & cgaaatgccacggtagaaat & ctgccttcggtattctgctc \\
\hline SMAD3/Smad3 & Transcription factor activity & 365 & ctgtgtgagttcgecttcaa & ggctcgcagtaggtaactgg \\
\hline SMAD4/Smad4 & Transcription factor activity & 350 & ggttgcacataggcaaaggt & gcgectctgaattactgtcc \\
\hline $\mathrm{SP} 1 / \mathrm{Sp} 1$ transcription factor & Transcription factor activity & 355 & ggagagcaaaaccagcagac & caatgggtgtgagagtggtg \\
\hline TCF3 / E12/E47 & Transcription factor activity & 567 & gcactggcetcgatctactc & ggccttcagctccttcttct \\
\hline $\begin{array}{l}\text { WWTR1(TAZ)/WW domain containing } \\
\text { transcription regulator } 1\end{array}$ & Transcription factor activity & 470 & gaggagatggcgtctaccag & gagctgctctgcctgagtct \\
\hline ZEB1/ZEB1 & Transcription factor activity & 537 & gcacctgaagaggaccagag & tggtgatgctgaaagagacg \\
\hline ZEB2/ZEB2 & Transcription factor activity & 393 & ttcctgggctacgaccatac & gecttgagtgctcgataagg \\
\hline $\begin{array}{l}\text { HIF1A/Hypoxia-inducible factor } 1 \alpha \\
\text { PARD6A/par-6 partitioning defective } 6\end{array}$ & Transcription factor binding & 424 & ccgtgtgtgtgtgtgtgtgt & ccaccagttgccetgactat \\
\hline homolog $\alpha$ & Transcription factor binding & 334 & gttgccaacagccataacct & agaggctgaagccactacca \\
\hline $\begin{array}{l}\text { FLT1(VEGFR1)/fms-related tyrosine } \\
\text { kinase } 1\end{array}$ & Transferase activity & 506 & aggggaagaaatcctccaga & gctcacactgctcatccaaa \\
\hline
\end{tabular}


Table I. Continued.

\begin{tabular}{lllll}
\hline Gene symbols/gene names & \multicolumn{1}{c}{ Gene ontology } & bp & 5' & 3 \\
\hline GSK3B/glycogen synthase kinase 3 3 & Transferase activity & 481 & accgcagaacctcttgttgg & tgttagtcgggcagttggtg \\
HAS1/hyaluronan synthase 1 & Transferase activity & 303 & accaattcccatcatttcca & ggttgtaccaggcctcaaga \\
HAS2/hyaluronan synthase 2 & Transferase activity & 463 & tttgggtgtgttcagtgcat & taaggcagctggcaaaagat \\
HAS3/hyaluronan synthase 3 & Transferase activity & 439 & gggagatgtccagatcctca & gaaacccgtgaccactgact \\
PORCN/porcupine homolog (Drosophila) & Transferase activity & 205 & tacctgaagcatgcaagcac & cggtgtctaccatgtgcatc \\
IL1R/interleukin 1 receptor, type I & Transmembrane receptor activity & 436 & ctggcacgtttgtgagaaga & gttccttcaagcaggcaaag \\
IL8RB/interleukin 8 receptor, B & Transmembrane receptor activity & 378 & cgctccgtcactgatgtcta & tgctgtattgttgcccatgt \\
\hline
\end{tabular}

$4^{\circ} \mathrm{C}$. The cells were then blocked with $5 \%$ BSA in T-TBS for $1 \mathrm{~h}$ and incubated with rabbit anti-human connexin 26 antibody (Invitrogen). After gentle washing with TBS, they were incubated with Alexa488 conjugated goat anti-rabbit IgG antibody (Invitrogen). Cells adhering to the beads were transferred carefully into TBS in a glass bottom culture dish. Immunofluorescence images were captured using a Keyence BZ-8000 microscope (Keyence, Japan).

Scanning electron microscopy. Following fixation with glutaraldehyde and $\mathrm{OsO}_{4}$ in $\mathrm{PBS}$, the cells were dehydrated in ascending concentrations of ethanol. After critical point drying using carbon dioxide and coating by vacuum-evaporated carbon and ion-spattered gold, specimens were observed by the JSM-35 (Jeol, Tokyo, Japan) at an accelerated voltage of $10 \mathrm{kV}$.

Statistical analysis. All data are expressed as mean \pm SD of at least triplicate measurements. The significance of the effect of each experiment $(\mathrm{p}<0.05)$ was determined by the Student's t-test analysis using StatView software.

\section{Results}

This is the first application of the RFB culture system to culturing of a squamous cell carcinoma cell line, instead of the hepatocellular carcinoma cell lines that are usually cultured in this apparatus. Ultrastructural observation revealed that A431 tumor cells grew well on the surface of a hydroxyl apatite matrix, with morphology of stratified squamous epithelial sheets with 5-6 cell-layers with an irregular shape (Fig. 1A). The free surface of the outer cells exhibited short but numerous blunt microvillous projections. The sheets of viable tumor cells invaded the narrow spaces of pores or gaps of the hydroxyl apatite beads.

Gradual-increase of TGF $\beta 1$ in CM from $3 D$ culture of $A 431$ cells. The TGFß1 levels in CM sampled from A431 cells cultured in RFB gradually increased and after 14 days reached an $\sim 2$-fold level above that at the initiation of culture (Fig. 1B). In contrast to the $3 \mathrm{D}$ culture conditions, A431 cells cultured under 2D monolayer conventional conditions, did not detect the increased accumulation of TGFß1 level during the same period of time. These results were confirmed by the mRNA expression assay. By RT-PCR and DNA microarray examinations, increased expression of TGFß1 and their receptors (TRßI, II) genes was noticed in 3D-cultured A431 cells as compared with that in 2D-cultured cells (Fig. 1C). The TGFß1 receptor-regulated Smads (Smad2 and Smad3) and commonpartner Smad (Smad4) did not show any remarkable difference in mRNA expression between 2D- and 3D-cultured cells. In our study, phosphorylation of Smad3 protein was found only in 3D-cultured cells (Fig. 1D). This result indicated that the $3 \mathrm{D}$ culture enhanced the production, secretion of TGFB1 and activation of the pathway by the autocrine mechanism of the A431 cells

Proteasome activities in tumor cells cultured either in $2 \mathrm{D}$ or $3 D$ systems. It is of interest that the proteasomal enzymatic activities in the cell extracts from 3D-cultured cells (activity: $0.636 \pm 0.121 \mathrm{nmol} / \mathrm{min} . \mathrm{mg}$ protein) were $\sim 3$ - and $1.5-2$ times higher than those from 2D-cultured cells $(0.219 \pm 0.019 \mathrm{nmol} /$ min.mg protein) and from nude mouse xenotransplantation $(0.472 \pm 0.057 \mathrm{nmol} / \mathrm{min} . \mathrm{mg}$ protein), respectively (Fig. 2A). Western blot analysis showed that P-32 and P-27 proteins ( $($-subunits of proteasome) increased in the cell extracts from 3D-cultured cells (Fig. 2B).

Analyses of transcriptional regulators for EMT. Fluctuation of gene expression between 2D- and 3D-cultured cells is shown in Table II. Because of enhanced autocrine secretion of TGFß1 by 3D-cultured A431 cells, gene expression of several transcriptional regulators that were regulated by TGFß1 was examined using RT-PCR analyses. As shown in Fig. 3A, well-known transcriptional repressors of E-cadherin gene were checked, such as Snai1, Slug (zinc finger proteins), ZEB1, ZEB2 (two-handed zinc finger/homeodomain proteins), E12/E47, Twist (basic helix-loop-helix, bHLH), Goosecoid [bicoid subfamily of the paired (PRD) homeobox family of proteins], FOXC2 (forkhead box protein C2) and LEF1 (high mobility box-containing proteins) and those involved in the EMT response to TGFß1 signaling. Among these repressors, Slug, Goosecoid and LEF1 were up-regulated in the 3Dcultured cells as compared with 2D-cultured cells. Additionally, Notch target HEY1 gene, a member of the hairy/enhancerof-split family of transcriptional repressors, was up-regulated in 3D-cultured cells, probably via activation of the TGFB1/ Smad3 pathway. HMGA2, a high-mobility group nuclear factor and down-stream key regulator of TGFß/Smad signaling, was expressed at a higher level in 3D-cultured cells than in 2D-cultured cells. Transcriptional repressors, such as the snail zinc finger protein family, two-handed zinc finger proteins, bHLH proteins and the high-mobility group box-containing proteins described above were regulated by HMGA2. 


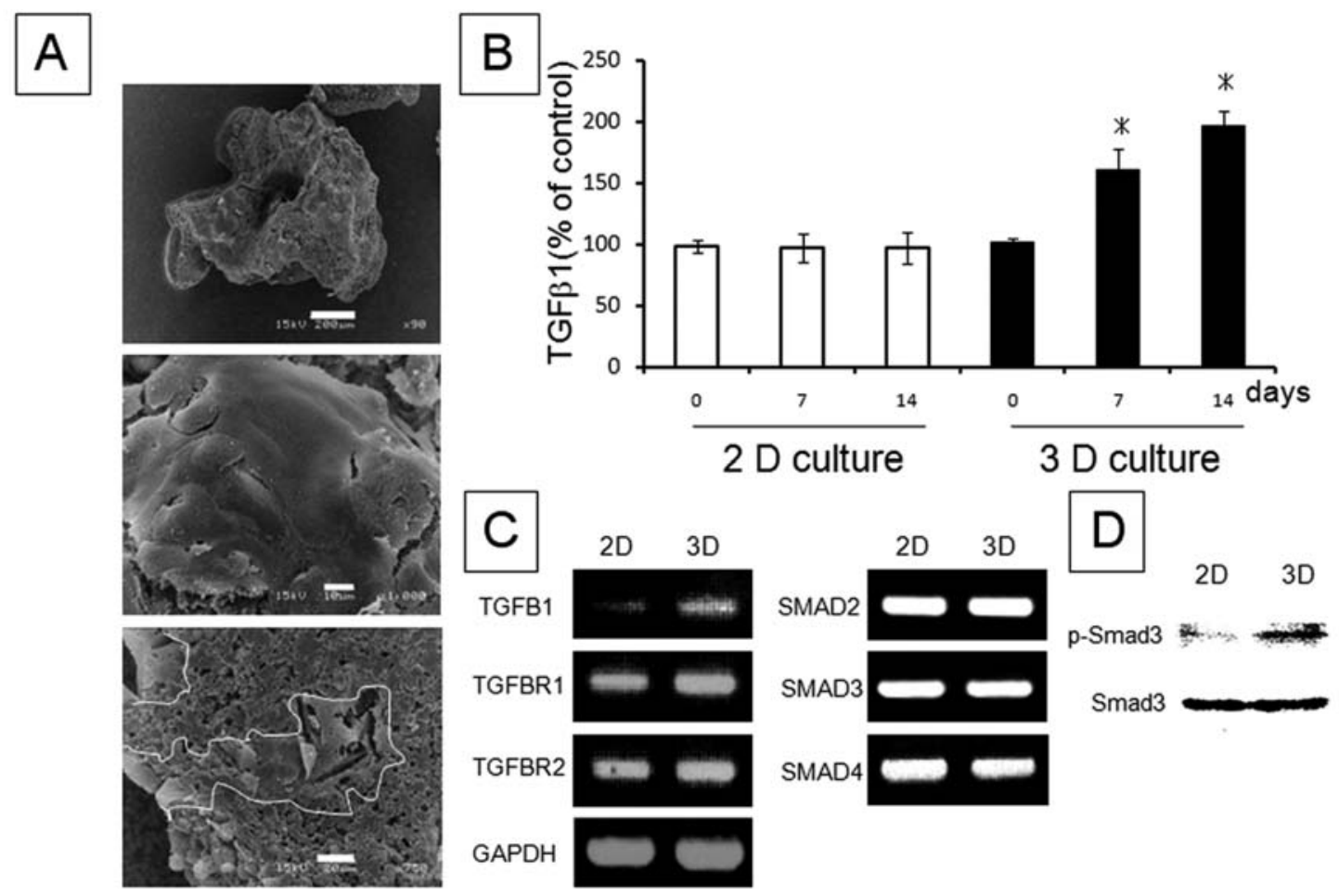

Figure 1. A431 cells, growing well in 3D, RFB culture system for 14 days, showed up-regulated TGFß1 signaling and secreted significant amounts of TGFß1 into the medium. (A) By scanning electron microscopy, A431 cells cultured under 3D conditions attached and grew with a stratified morphology on hydroxyl apatite beads. Some cells invaded into the narrow spaces of scaffold (indicated as marker line). Bar scales $200 \mu \mathrm{m}$ (upper panel), $10 \mu \mathrm{m}$ (middle panel) and $20 \mu \mathrm{m}$ (lower panel), respectively. (B) In 3D culture, A431 cells secreted significant amounts of TGFß1, time-dependently. Conditioned media (CM) from each culture system were assayed with TGFß1 ELISA. Data showed percent increase of TGFß1 in control growth media. Details are given in the Materials and methods section. ${ }^{*}<0.05$, significant difference from 0 day. (C) Up-regulated mRNA expression of TGFB1 and its receptors in 3D-cultured cells. mRNAs of Smad2, -3 , and -4 showed no changes. Cells in either a 2D or 3D culture system were maintained for 14 days and the gene expression were measured by RT-PCR. (D) Phosphorylated (p) Smad3 increased only in 3D-cultured cells. After 14 days of culture, cells were harvested from either the 2D or 3D culture system and cell lysates were analyzed by Western blotting.

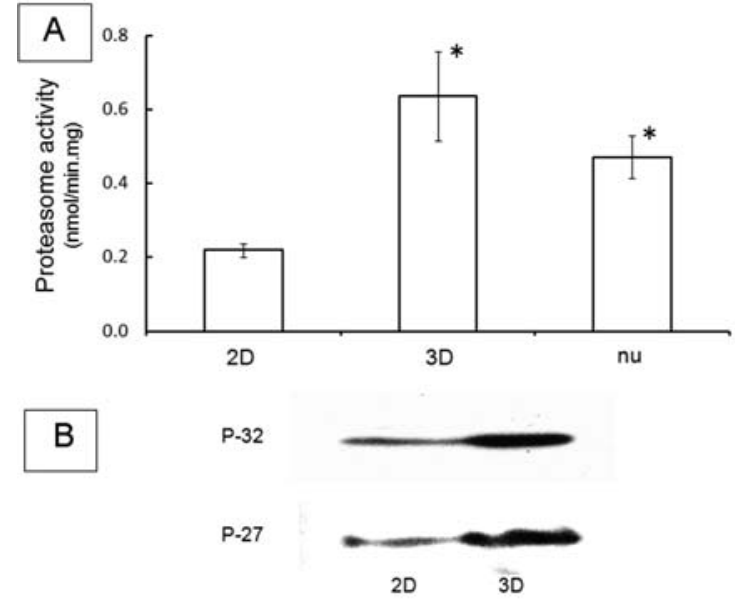

Figure 2. A431 cells cultured under 3D conditions showed increased proteasomal activity. A431 cells were cultured for 14 days under either 2D or 3D conditions. A431 cells $\left(5 \times 10^{6}\right)$ were also transplanted subcutaneously into nude mice and after 4 weeks of transplantation, tumor tissues (nu) were obtained. Cell lysate from each of the respective tumor cells was analyzed. (A) Proteasomal activity was determined using suc-LLVY-AMC as the substrate. Fluorescence at Ex.380nm/Em.460 nm was measured. ${ }^{*}<0.05$, significant difference from 2D. (B) Western blot analysis with antibodies against $B$-subunits of proteasome showed extremely increased bands in 3Dcultured cells.

Additionally, gene expression of HMGA2-downstream Id2 (inhibition of DNA binding 2) was down-regulated in the 3D-cultured A431 cells in the present study. Expression of
NF- $\mathrm{B}$ and AP1 were slightly up-regulated, but other regulators, such as CUTL1 (homeoproteins CDP), SP1 (KLF-like zinc finger) or csl (recombination signal binding protein for immunoglobulin $\kappa \mathrm{J}$ region, RBPJ identical to $\mathrm{CBF} 1 /$ suppressor of hairless/Lag1), showed no remarkable changes in the present study. Id genes, which are down-stream of the TGFß1 signaling gene, play a critical role in E-cadherin expression because of their repressive effect on bHLH transcriptional factors. It seems likely that the increased TGFß1 signaling in this culture system promoted the subsequent decrease of E-cadherin. Moreover, the several transcriptional regulators down-stream of the TGFß1 signaling pathway described above were also up-regulated to various degrees in A431 cells transplanted in nude mice.

Autocrined TGFß1 promotes gene expression related to EMT. E-cadherin, well known as an epithelial marker, was first examined. The mRNA expression of the gene showed no significant difference between the 2D- and 3D-cultured cells, whereas Western blot analysis revealed a significant 1.6- to 2.4-fold decrease in E-cadherin protein in the 3D-cultured A431 cells as compared to 2D cells (Fig. 3A,B). Conversely, a soluble $80-\mathrm{kDa}$ fragment of E-cadherin in shedding form was increased time-dependently in CM from both 2D and 3D culture systems (Fig. 4A). Accumulation of the E-cadherin fragment in the media from $3 \mathrm{D}$ culture was at a much higher level and more rapid than from 2D culture. MMP7 (both mRNA and protein levels) was increased in 3D-cultured cells 
Table II. Expression of representative genes in 3D-cultured vs. 2D cells (Microarray analysis).

\begin{tabular}{|c|c|c|c|}
\hline Probe set ID & Gene name & Gene symbol & Fold expression \\
\hline \multicolumn{4}{|l|}{ Upregulated } \\
\hline 221009_s_at & Angiopoietin-like 4 & ANGPTL4 & 66.4 \\
\hline 202628_s_at & Serine (or cysteine) proteinase inhibitor, clade E, member 1 & SERPINE1 & 34.77 \\
\hline 205680_at & Matrix metallopeptidase 10 (stromelysin 2) & MMP10 & 26.13 \\
\hline 201426_s_at & Vimentin & VIM & 18.74 \\
\hline 230372_at & Hyaluronan synthase 2 & HAS2 & 18.61 \\
\hline 203691_at & Protease inhibitor 3, skin-derived (SKALP) & PI3 & 17.04 \\
\hline 223278_at & Gap junction protein, $32,26 \mathrm{kDa}$ (connexin 26) & GJB2 & 11.43 \\
\hline 204298_s_at & Lysyl oxidase & LOX & 11.09 \\
\hline 209800_at & Keratin 16 (focal non-epidermolytic palmoplantar keratderma) & KRT16 & 10.6 \\
\hline 203963_at & Carbonic anhydrase XII & CA12 & 10.05 \\
\hline 203726_s_at & Laminin, $\alpha 3$ & LAMA3 & 9.6 \\
\hline 209365_s_at & Extracellular matrix protein 1 & ECM1 & 9.22 \\
\hline 215867_x_at & $\gamma$-adaptin & AP1G1 & 8.43 \\
\hline 1558683_a_at & High mobility group AT-hook 2 & HMGA2 & 7.53 \\
\hline 205199_at & Carbonic anhydrase IX & CA9 & 6.22 \\
\hline 204636_at & Collagen, type XVII, $\alpha 1$ & COL17A1 & 5.87 \\
\hline 214580_x_at & Keratin $6 \mathrm{~A}$ & KRT6A & 5.82 \\
\hline 211160_x_at & Actinin, $\alpha 1$ & ACTN1 & 5.64 \\
\hline 219483_s_at & Porcupine homolog (Drosophila) & PORCN & 5.62 \\
\hline 210248_at & Wingless-type MMTV integration site family, member 7A & WNT7A & 5.59 \\
\hline 212464_s_at & Fibronectin 1 & FN1 & 5.43 \\
\hline 203939_at & 5'-nucleotidase, ecto (CD73) & NT5E & 5.06 \\
\hline 201389_at & Integrin, $\alpha 5$ (fibronectin receptor, $\alpha$ polypeptide) & ITGA5 & 4.93 \\
\hline 209126_x_at & Keratin 6B & KRT6B & 4.9 \\
\hline 209118_s_at & Tubulin, $\alpha 3$ & TUBA3 & 4.79 \\
\hline 219764_at & Frizzled homolog 10 (Drosophila) & FZD10 & 4.57 \\
\hline 226535_at & Integrin, $B 6$ & ITGB6 & 4.5 \\
\hline 203423_at & Retinol binding protein 1 , cellular & RBP1 & 4.49 \\
\hline 209099_x_at & Jagged 1 (Alagille syndrome) & JAG1 & 4.44 \\
\hline 209270_at & Laminin, $B 3$ & LAMB3 & 4.29 \\
\hline 205067_at & Interleukin $1, \beta$ & IL1B & 4.17 \\
\hline 235075_at & Desmoglein 3 (pemphigus vulgaris antigen) & DSG3 & 4.12 \\
\hline 202267_at & Homo sapiens laminin, $\gamma 2$ (LAMC2), transcript variant 2 , mRNA. & LAMC2 & 4.11 \\
\hline 201945_at & Furin (paired basic amino acid cleaving enzyme) & FURIN & 4.09 \\
\hline 218368_s_at & Tumor necrosis factor receptor superfamily, member $12 \mathrm{~A}$ & TNFRSF12A & 3.9 \\
\hline 200696_s_at & Gelsolin (amyloidosis, Finnish type) & GSN & 3.79 \\
\hline 202284_s_at & Cyclin-dependent kinase inhibitor 1A (p21, Cip1) (CDKN1A) & CDKN1A & 3.75 \\
\hline 202345_s_at & Fatty acid binding protein 5 (psoriasis-associated) & FABP5 & 3.73 \\
\hline 203821_at & Diphtheria toxin receptor (heparin-binding epidermal growth factor like growth factor) & HBEGF & 3.66 \\
\hline 206461_x_at & Metallothionein $1 \mathrm{H}$ & MT1H & 3.66 \\
\hline 201110_s_at & Thrombospondin 1 & THBS1 & 3.64 \\
\hline 211527_x_at & Vascular endothelial growth factor & FLT1 & 3.62 \\
\hline 201464_x_at & v-jun sarcoma virus 17 oncogene homolog (avian) & JUN & 3.59 \\
\hline 201069_at & Matrix metalloproteinase 2 (gelatinase A, $72 \mathrm{kDa}$ gelatinase) & MMP2 & 3.55 \\
\hline 202733_at & Procollagen-proline, 2-oxoglutarate 4-dioxygenase, alpha polypeptide II & P4HA2 & 3.51 \\
\hline 209720_s_at & Serine proteinase inhibitor, clade B (ovalbumin), member 3 & SERPINB3 & 3.44 \\
\hline 212741_at & Monoamine oxidase A & MAOA & 3.37 \\
\hline 205157_s_at & Keratin 17 & KRT17 & 3.36 \\
\hline 202575_at & Cellular retinoic acid binding protein 2 & CRABP2 & 3.33 \\
\hline 209344_at & Tropomyosin 4 & TPM4 & 3.29 \\
\hline 202998_s_at & Lysyl oxidase-like 2 & LOXL2 & 3.18 \\
\hline 202638_s_at & Intercellular adhesion molecule 1 (CD54), human rhinovirus receptor & ICAM1 & 3.07 \\
\hline 201656_at & Integrin, $\alpha 6$ & ITGA6 & 3.06 \\
\hline 227761_at & Myosin VA (heavy polypeptide 12 , myoxin) & MYO5A & 3.06 \\
\hline 225227_at & SKI-like & SnoN & 3.02 \\
\hline
\end{tabular}


Table II. Continued.

\begin{tabular}{|c|c|c|c|}
\hline Probe set ID & Gene name & Gene symbol & Fold expression \\
\hline 202934_at & Hexokinase 2 & HK2 & 2.98 \\
\hline 209835_x_at & CD44 antigen (homing function and Indian blood group system) & CD44 & 2.97 \\
\hline 231766_s_at & Homo sapiens collagen, type XII, $\alpha 1$ (COL12A1), transcript variant short, mRNA & COL12A1 & 2.95 \\
\hline 226342_at & Spectrin, $ß$, non-erythrocytic 1 & SPTBN1 & 2.92 \\
\hline 202833_s_at & Serine proteinase inhibitor, clade A (v-1 antiproteinase, antitrypsin), member 1 & SERPINA1 & 2.9 \\
\hline 226452_at & Pyruvate dehydrogenase kinase, isoenzyme 1 & PDK1 & 2.82 \\
\hline 204750_s_at & Desmocollin 2 & DSC2 & 2.77 \\
\hline 211668_s_at & Plasminogen activator, urokinase & PLAU & 2.71 \\
\hline 201125_s_at & Integrin, $\beta 5$ & ITGB5 & 2.67 \\
\hline 211985_s_at & Calmodulin 1 (phosphorylase kinase, $\Delta$ ) & CALM1 & 2.67 \\
\hline 205016_at & Transforming growth factor, $\alpha$ & TGFA & 2.63 \\
\hline 203085_s_at & Transforming growth factor, $B 1$ (Camurati-Engelmann disease) & TGFB1 & 2.59 \\
\hline 221530_s_at & Basic helix-loop-helix domain containing, class B, 3 & BHLHB3 & 2.58 \\
\hline 211981_at & Collagen, type IV, $\alpha 1$ & COL4A1 & 2.57 \\
\hline 218507_at & Hypoxia-inducible protein 2 & HIG2 & 2.51 \\
\hline 227271_at & Fibroblast growth factor 11 & FGF11 & 2.42 \\
\hline 204259_at & Matrix metalloproteinase 7 (matrilysin, uterine) & MMP7 & 2.39 \\
\hline 204858_s_at & Endothelial cell growth factor 1 (platelet-derived) & ECGF1 & 2.3 \\
\hline \multicolumn{4}{|l|}{ Downregulated } \\
\hline 204664_at & Alkaline phosphatase, placental (Regan isozyme) & ALPP & 0.0102 \\
\hline 201566_x_at & Inhibitor of DNA binding 2, dominant negative helix-loop-helix protein & ID2 & 0.0188 \\
\hline 208146_s_at & Carboxypeptidase, vitellogenic-like & CPVL & 0.0256 \\
\hline 205524_s_at & Hyaluronan and proteoglycan link protein 1 & HAPLN1 & 0.0288 \\
\hline 220921_at & SPANX family, member A2 & SPANXA2 & 0.0304 \\
\hline 203770_s_at & Steroid sulfatase (microsomal), arylsulfatase $\mathrm{C}$, isozyme $\mathrm{S}$ & STS & 0.036 \\
\hline 204836_at & Glycine dehydrogenase (decarboxylating) & GLDC & 0.0459 \\
\hline 207069_s_at & SMAD, mothers against DPP homolog 6 (Drosophila) & SMAD6 & 0.0624 \\
\hline 203954_x_at & Claudin 3 & CLDN3 & 0.068 \\
\hline 215977_x_at & Glycerol kinase & GK & 0.0785 \\
\hline 226237_at & Collagen, type VIII, $\alpha 1$ & COL8A1 & 0.0943 \\
\hline 238851_at & Ankyrin repeat domain $13 \mathrm{~A}$ & ANKRD13A & 0.103 \\
\hline 220115_s_at & Cadherin 10, type 2 (T2-cadherin) & CDH10, & 0.103 \\
\hline 207160_at & Interleukin $12 \mathrm{~A}$ & IL12A & 0.104 \\
\hline 206392_s_at & Retinoic acid receptor responder (tazarotene induced) 1 & TIG1 & 0.106 \\
\hline 201852_x_at & Collagen, type III, $\alpha 1$ (Ehlers-Danlos syndrome type IV, autosomal dominant) & COL3A1 & 0.106 \\
\hline 233720_at & Arg/Abl-interacting protein ArgBP2 & SORBS2, & 0.108 \\
\hline 225202_at & Rho-related BTB domain containing 3 & RHOBTB3 & 0.115 \\
\hline 205698_s_at & Mitogen-activated protein kinase kinase 6 & MAPKK6 & 0.128 \\
\hline 239219_at & Aurora kinase B & AURKB & 0.132 \\
\hline 206110_at & Histone $1, \mathrm{H} 3 \mathrm{~h}$ & HIST1H3H & 0.134 \\
\hline 209291_at & Inhibitor of DNA binding 4, dominant negative helix-loop-helix protein & ID4 & 0.138 \\
\hline 206336_at & Chemokine (C-X-C motif) ligand 6 (granulocyte chemotactic protein 2) & CXCL6 & 0.141 \\
\hline 210176_at & Toll-like receptor 1 & TLR1 & 0.146 \\
\hline 203946_s_at & Arginase, type II & ARG2 & 0.147 \\
\hline 222043_at & Clusterin & CLU & 0.15 \\
\hline
\end{tabular}

(Fig. 3A and B and 5A) and casein zymogram demonstrated the increased activity of MMP7 in CM only obtained from 3D culture condition (Fig. 5B). Interestingly, addition of recombinant human MMP7 to the media also promoted the accumulation of $80-\mathrm{kDa}$ fragments in the media, even if the A431 cells were cultured under 2D conditions (Fig. 4B).

Additionally, as shown in Fig. 3B, increased mRNA and protein levels of $B$-catenin were detectable in $3 \mathrm{D}$-cultured cells compared to $2 \mathrm{D}$-cultured cells. The mRNA and protein expression of keratin 18, another epithelial marker, were down-regulated slightly in the 3D-cultured cells. By contrast, the mRNAs and proteins of vimentin and fibronectin, known as common mesenchymal markers, in 3D-cultured cells were highly expressed, whereas these two proteins were undetectable by Western blot analysis in 2D-cultured cells. It is of interest that the A431 tumor tissues xenotransplanted into nude mice also showed slight but obvious expression of the mRNAs of these two molecules, as compared with 2D-cultured cells, 
A

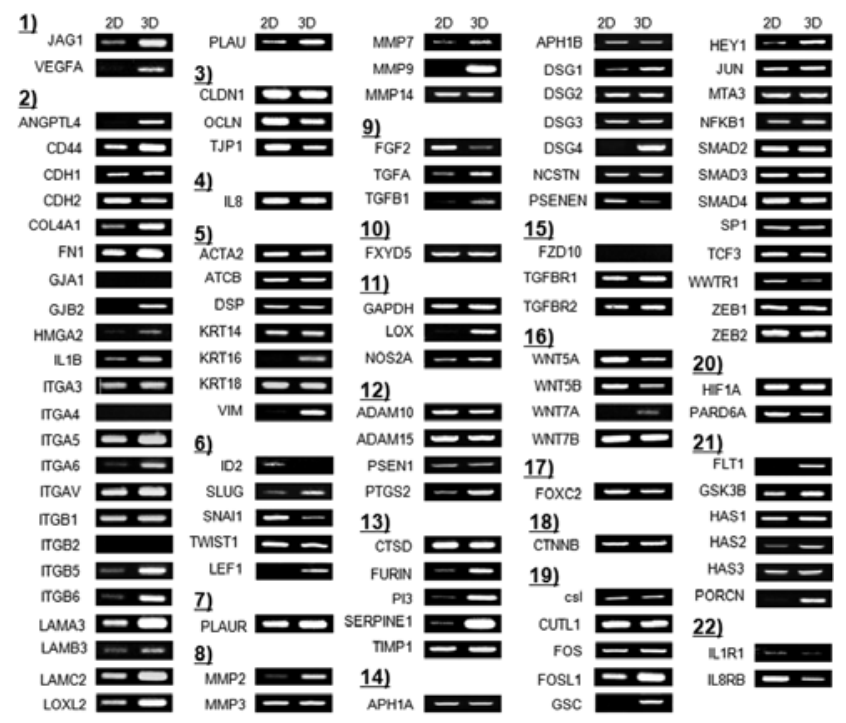

C

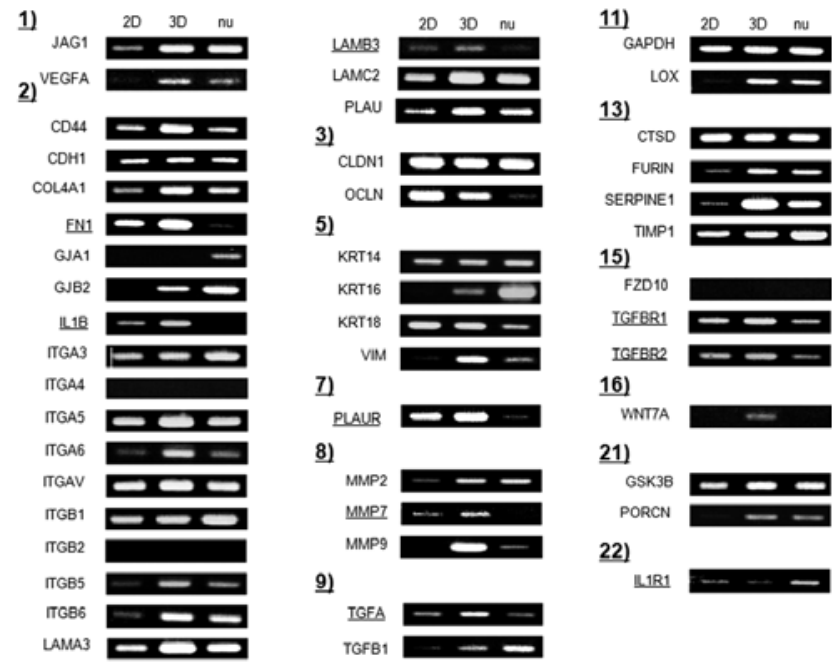

however, the expression was weaker than in 3D-cultured cells (Fig. 3C).

Since TGFß1 not only activates Smad signaling, but also affects the activity of various non-Smad or other Smad-related signaling effectors, a number of which have an impact on EMT, a vast amount of proteins is involved and cross-talked in EMT processes. The 3D-cultured tumor cells had high levels of induced phosphorylation of MKK4 (JNKK), compared to ERK1 (Fig. 3B). Interestingly, in 3D-cultured cells, the Notch and Wnt signal pathways were stimulated to a relatively higher level than in the $2 \mathrm{D}$-cultured cells as well as nude mice-derived tumor cells (Fig. 3C). TGFß signaling can induce JAG1 (Jagged-1) expression, one of the Notch ligands, and might have activated the Notch signaling pathway in the present study. On the other hand, Wnt7A, a secreted factor known as the Wnt family of cysteine-rich glycoproteins with hydrophobic signal peptides, was only overexpressed in 3D-cultured cells. Additionally both $\beta$-catenin and glycogen synthase kinase (GSK)-3ß mRNAs showed slightly increased
B

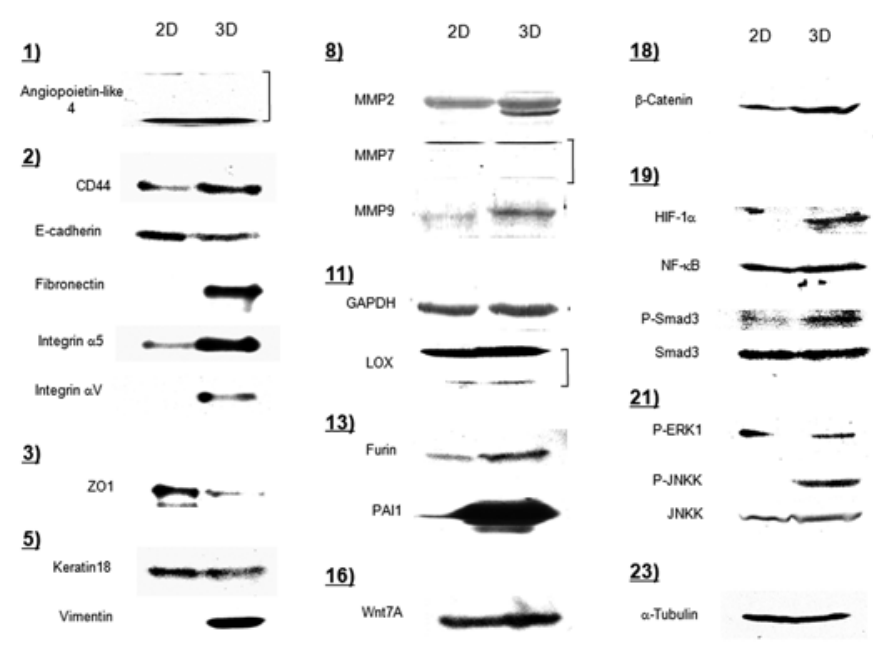

Figure 3. Several representative key genes of EMT expressed in A431 tumor cells cultured under 3D conditions. Tumor cells were cultured for 14 days under either $2 \mathrm{D}$ or $3 \mathrm{D}$ conditions. Other tumor cells were subcutaneously transplanted into nude mice for 4 weeks. mRNAs were extracted and gene expression was measured by RT-PCR (A and C). Extracted cell lysates were subjected to SDS-PAGE followed by Western blot analyses (B). The 3D- and 2D-cultured tumor cells (A), as well as nude mice-transplanted tumor cells (C) were compared. Underlined-gene symbols indicate the discrepancy of mRNA expressions between 2D, 3D and nude mice (nu) derived tumor cells $(\mathrm{C})$. The numbers indicate the names in gene ontologic classification. 1) Angiogenesis, 2) Cell communication, 3) Cell junction, 4) Chemokine activity, 5) Cytoskeleton, 6) DNA binding, 7) Enzyme binding, 8) Extra-cellular matrix protein, 9) Growth factor activity, 10) Ion channel activity, 11) Oxidoredactase activity, 12) Peptidase activity, 13) Protease, 14) Protein binding, 15) Receptor activity, 16) Signal transducer activity, 17) Transcription activating factor, 18) Transcription coactivator activity, 19) Transcriptional factor activity, 20) Transcriptional factor binding, 21) Transferase activity, 22) Transmembrane receptor activity, 23) Structural molecule activity. expression in 3D-cultured cells. By contrast, mRNAs of Wnt7B, Wnt5A, and Wnt5B were down-regulated to levels ranging from slight to moderate in $3 \mathrm{D}$-cultured cells. Frizzled 10 message could not be detected in the present study, in spite of upregulation in microarray assay (Table II). Because of enhanced co-expression of the Porcupine gene, which is an essential partner of Wnt secretion and a protein with structural similarities to membrane-bound O-acyl transferases, Wnt protein secretion might be activated in the 3D-cultured A431 cells.

Down-regulation of the epithelial-specific proteins (Ecadherin and cytokeratin 18) and the concomitant gain of various mesenchymal proteins (vimentin and fibronectin) suggest that the EMT-like processes occurred in squamous cell carcinoma cells under 3D culture conditions. EMT was found to be associated with the acquisition of a fibroblastoid migratory morphology and related features. Addition of epithelial markers revealed down-regulation in the present study, with disintegration of cell-cell adhesion and detectable 

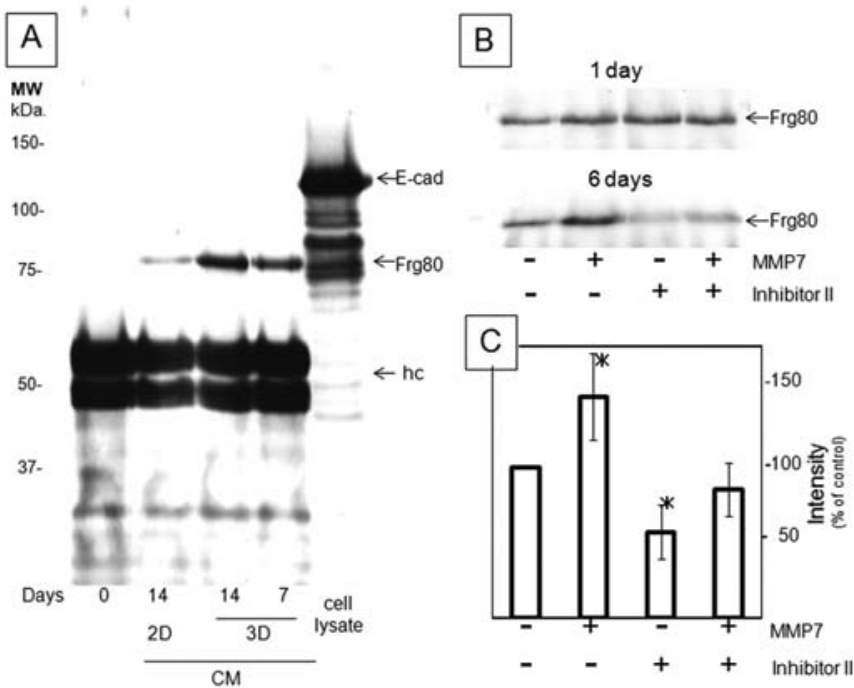

Figure 4. Time-dependent increase of $80-\mathrm{kDa}$ fragment of E-cadherin in $\mathrm{CM}$ from 3D-cultured A431 cells. A431 cells were cultured under (A) 3D for 14 days or (B) 2D conditions for 6 days. CM were analyzed by immunoprecipitation followed by Western blotting. (A) Time-dependent increases of $80-\mathrm{kDa}$ fragment of E-cadherin were detectable in the medium from the 3D culture system. (B) A431 cells were cultured without (as control) or with recombinant human (rh) MMP7 and/or its inhibitor (Inhibitor II) for 6 days. rh MMP7 promoted the shedding of E-cadherin, while, the addition of Inhibitor II decreased the fragments (showing a representative experiment). (C) Densitometric analysis of each band at 6 days after the treatment $(n=8)$. Intensities of bands from non-treated cells were used as control. ${ }^{*}<0.05$, significant difference from control. Cell lysate, A431 whole cell lysate. E-cad, E-cadherin; Frag 80, 80-kDa fragment of E-cadherin; hc, heavy chain of immunoglobulin G.

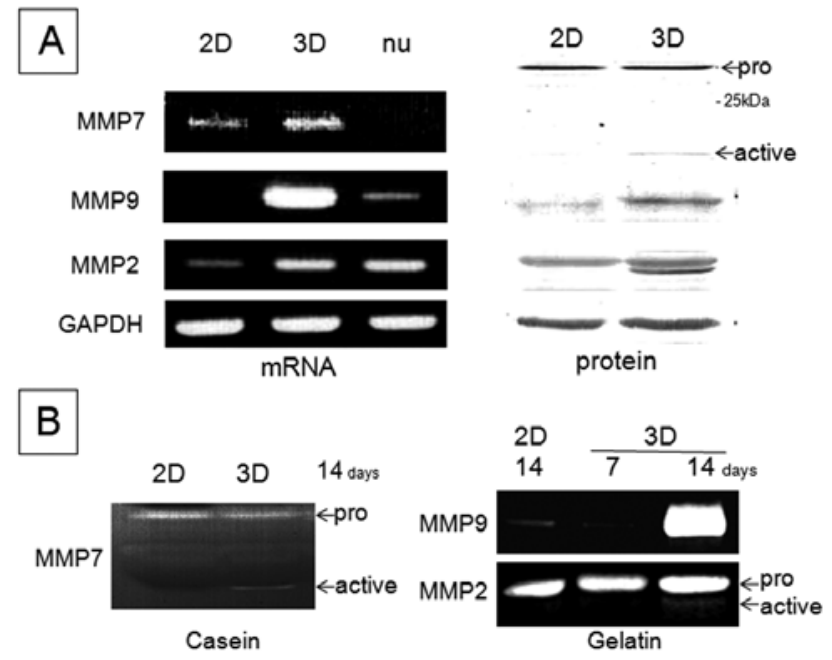

Figure 5. 3D-cultured cells showed up-regulated the MMP2, -7, and -9 gene expression and activated enzyme activities. A431 cells were cultured under either $2 \mathrm{D}$ or $3 \mathrm{D}$ conditions for 14 days. (A) The gene expression was measured by RT-PCR and corresponding proteins were analyzed by Western blotting. (B) Harvested CM were separated by SDS-PAGE under non-reducing conditions without heat using gels containing gelatin (for MMP2, and -9) and casein (for MMP7), respectively. After incubation of the gels at $37^{\circ} \mathrm{C}$ for $18 \mathrm{~h}$, they were stained by Coomassie and destained by methanol/acetate.

loss of epithelial polarity in the 3D-cultured cells, leading to loss of their epithelial properties. The messages of tight junctional proteins, such as occuludin, claudin, ZO-1 (also protein level) and epithelial polarity regulating Par6, were

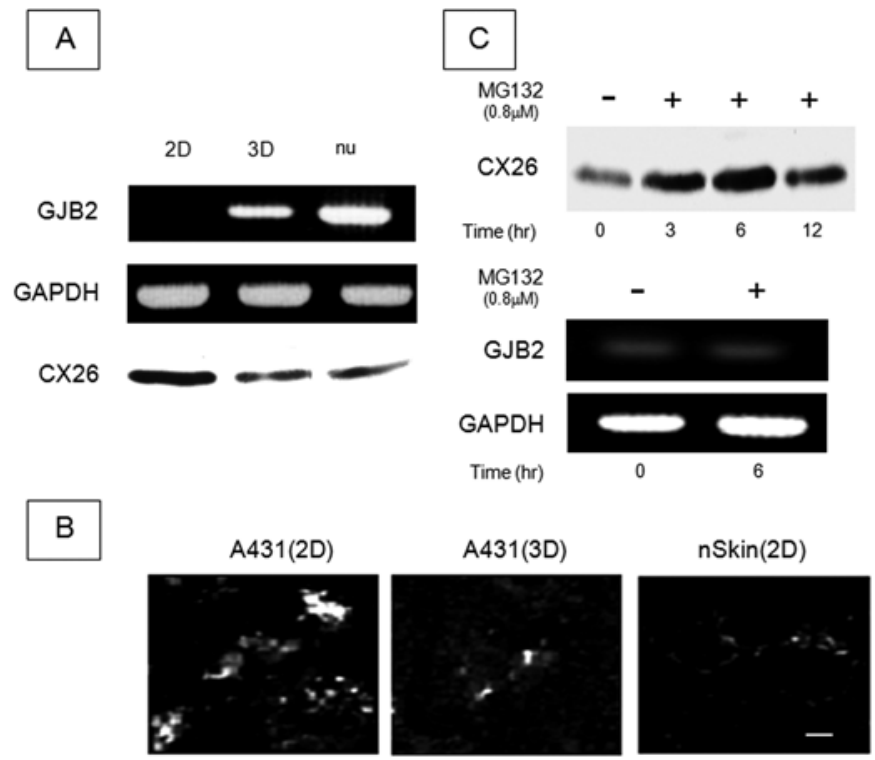

Figure 6. Discrepancy between connexin26 protein and its gene expression level was probably caused by increased enzyme activity of proteasome in 3D-cultured cells. (A) A431 cells were cultured under either 2D or 3D conditions for 14 days. Other A431 cells were transplanted into nude mice subcutaneously for 4 weeks. Cells and tissues were harvested and analyzed. GJB2 (CX26 gene) expression and the protein contents were analyzed by RT-PCR and Western blotting, respectively, by the method described in the Materials and methods section. (B) 3D- and 2D-cultured A431 cells were washed, fixed and immunostained indirectly using anti-CX26 antibody followed by Alexa488-labeled anti-rabbit IgG. Human normal skin squamous cells (nSkin) for control cells were cultured under 2D conditions and examined. Bar scale, $100 \mu \mathrm{m}$. (C) A431 cells were cultured under 2D conditions with/without MG132. After the indicated time intervals, cells were harvested and examined by Western blotting and RT-PCR. nu, nude mice bearing transplanted A431 cells. CX26, connexin26.

down-regulated in various degrees in the 3D cells. In contrast to the tight junctional proteins, mRNA expression of intracellular desmosomal components, such as desmogleins and desmoplakin, did not show any obvious changes in the cells under either of the two different culture conditions. The mRNA expressions of gap junctional connexin 26 and -43 in $3 \mathrm{D}$-cultured cells were up-regulated as compared to those in 2D-cultured cells during the EMT process. To confirm our result, respective connexin26 protein levels in $2 \mathrm{D}$ - and $3 \mathrm{D}$ cultured cells were further analyzed by Western blotting as well as by immunohistology (Fig. 6A and B). Interestingly, the protein level of connexin26 in 3D-cultured cells was found by both Western blotting and immunohistological analyses to be extremely reduced, as compared with the levels in 2Dcultured cells. Western blot analysis demonstrated that treatment of the cells with MG132 (at $0.8 \mu \mathrm{M})$, a proteasome inhibitor, induced rapid accumulation of intracellular connexin 26 protein within $3 \mathrm{~h}$, without any remarkable effect on the mRNA levels (Fig. 6C).

In order to lose their epithelial structure and migrate through interstitial extracellular matrices, the migrating cells need to dissolve the adjacent surrounding matrices including the basal lamina. Accordingly, shown in Figs. 3 and 5, either the mRNA or protein levels of proteolytic enzymes and their related proteins such as MMP2, -7, -9, furin which is known as a cleavage endopeptidase, and urokinase type PA (uPA), and its related proteins [uPA receptor (UPAR) and PAI-1], 
were all up-regulated. Several integrin subunits were upregulated during the $3 \mathrm{D}$ culture. In particular, both the mRNA and protein levels of integrin $\alpha_{5}$ (partner known as the fibronectin receptor, integrin $\alpha_{5} \beta_{1}$ ) and integrin $\alpha_{v}$ (partner known as the receptor for tenascin and fibronectin, integrin $\alpha_{5} \beta_{6}$ ) were up-regulated to release and bind the epithelial cell layer to the surrounding ECM. Additional overexpression of CD44 (hyaluronan receptor) and hyaluronan synthases were also detectable. It is of interest that the mRNAs of laminin-5 (laminin $\alpha_{3}, \alpha_{3}, \gamma_{2}$ ), which are well known as potent invasion markers for cancer cells, were markedly up-regulated in $3 \mathrm{D}$-cultured cells as compared with those in 2D cells and in nude mice-transplanted tumor cells. To remodel the extracellular matrices for the formation of microvessels, it was predicted that the TGFß1 secreted from tumor cells participated in and promoted tumor angiogenesis via inductions of TßRII, VEGF, VEGFR1, angiopoietin-like 4 and the LOX family (LOX, and LOX-like 2).

Discrepancy of mRNA expression in several genes between $2 D$-, 3D- and nude mice-derived tumor cells. Showing in underlined gene symbols in Fig. 3C, mRNAs of several molecules, which were upregulated in $3 \mathrm{D}$-cultured cells as compared to 2D ones, did not increase parallel, but rather decrease in the expression of mRNA levels in nude micetransplanted cells. Expression of mRNAs in other molecules examined almost fluctuated parallel in various degrees by the shift of the surrounding condition from 2D to 3D or nude mice in vivo.

\section{Discussion}

The present experiment was the first attempt to culture tumor cells derived from squamous cells, instead of a hepatoma cell in the RFB (5,9-11). It was demonstrated in the present study that the RFB system scaffolding with hydroxyl apatite beads was effective for culturing A431 squamous cell carcinoma cells to induce 3D growth by mimicking the architecture of the in vivo environment, and was a suitable in vitro tool for cancer research.

Interestingly, A431 tumor cells cultivated in RFB secreted a significantly increased amount of TGFß1 into media in a time-dependent manner. The ability of A431 tumor cells to secrete TGFß1 was demonstrated sufficiently by the upregulation of its mRNA in the tumor cells. In addition, the fact that the mRNAs of the TGFß receptors also were up-regulated in the tumor cells suggests that they were autocrined from the A431 cells. By contrast, the A431 tumor cells cultivated in the $2 \mathrm{D}$ culture system during the same period of time did not recognize either the up-regulation of TGFß1 mRNA or the accumulation of TGFß1 in the medium. These data strongly indicated that expression of the autocrine ability of TGFB1 in tumor cells seemed to be a result of their culture in a $3 \mathrm{D}$ environment. A possible autocrine loop in an in vitro culture system has been reported previously to be the TGFß loop $(16,23)$ in studies of tumor cell cultures. There have also been clinical research studies demonstrating that overexpression of the TGFß1 gene in tumor cells is a cause of the increase in the plasma TGFß1 level of patients bearing cancers, which is regarded as the clinically important prognostic factor $(24,25)$.
The elevated autocrine levels of TGFß1 mRNA and its protein were well-characterized in squamous cells during carcinogenesis (26-29), while it has been recognized neither in the RFB nor in the spheroid cultures of liver cell in several previous studies $(5,11)$, except for TGFß1 effects on hepatoma cells cultivated in a monolayer or in Matrigel $(30,31)$.

TGFß signaling is involved in tissue homeostasis and cancer development and is known to be a major regulator of EMT (16-18,20,21,28,30-39); it has also been implicated saliently in skin cancer development $(8,20)$. Classes of molecules during the EMT change are causally involved, including growth factors, transcription factors, adhesion molecules, cytoskeletal modulators and extracellular matrices proteases and their modulators. Other molecular changes seem to occur coincidently or after the initial behavioral change; for example, there is often a trend for cytokeratin intermediate filaments to be replaced with other types, typically vimentin as described above. As the squamous cell carcinoma A431 cells cultured in the RFB showed obvious overexpression of TGFß1 with its receptors and established an autocrine loop in the cells (23), a consequent decrease in the protein expression of E-cadherin and cytokeratin 18, known as representative epithelial markers, was induced in the cells. On the other hand, expression of mesenchymal markers, such as vimentin and fibronectin, increased in the cells under 3D culture conditions in comparison with $2 \mathrm{D}$ culture. The changes in some proteins tested were also recognized even in tumor tissues from A431 cells xenotransplanted into nude mice. This fact verified that the microenvironment of the A431 tumor cells undergoing $3 \mathrm{D}$ culture in the RFB was equivalent in part to that of in vivo animal transplantation of the cells and it strongly supported the notion that expression and maintenance of several tumor-specific cell functions are possible under the defined RFB circumstances, as described in previous studies on the characterization of hepatocellular carcinoma cell lines using RFB culture $(5,9-11)$.

In the characterizations of A431 tumor cells cultured in RFB, several of the demonstrated molecular up- or downregulations were fundamental and characteristic changes of EMT. Down-regulation of E-cadherin is known as the representative and initial phenotypic event of the EMT process. In the present study, the level of E-cadherin protein decreased substantially in 3D-cultured cells as compared with 2Dcultured cells, whereas the expression level of E-cadherin mRNA did not show any obvious difference between the two types of culture. It has been noted that the suppression of E-cadherin has been linked to various transcriptional regulators that bind the promoter of the E-cadherin gene to repress its transcription (16-18,20,21,27,31-33,35,36,38-41). In this study, only three E-cadherin-repressing regulators, Slug, Goosecoid and LEF1, were up-regulated. There seems to be no rule on which of the transcriptional repressors of E-cadherin is stimulated as described previously $(8,18,42)$. In particular, a gene-targeting knock-down experiment with one of the transcriptional repressors genes, such as SNAI1, did not show any significant reduction in the level of E-cadherin or ß-catenin (42), suggesting that a multifactorial regulation mechanism is associated with the life cycle of the E-cadherin molecule. The discrepancy between mRNA and protein levels of E-cadherin in the 3D-cultured cells was demonstrated by 
increased accumulation of the soluble $80-\mathrm{kDa}$ form of $\mathrm{E}$ cadherin in spent culture medium from the RFB (3D) culture as compared with that from the monolayer (2D) culture. The present study and a recent review (43) showed that MMP7 was able to cleave and shed digestive E-cadherin at the cell surface and to release the soluble fragments into the medium. Furthermore, the $80-\mathrm{kDa}$ fragments promoted the induction of MMP2, -9 and -14 $(43,44)$. In a clinical setting, high levels of cleaved E-cadherin fragments have been detected in cancer tissue (45) as well as in serum and urine (46) from cancer patients. A431 tumor cells, cultured under 3D conditions, showed increased expression of MMP7 in both gene and protein levels as compared with the cells cultured under 2D conditions among several effectors in the E-cadherin shedding mechanisms (45). It has been substantiated that the TGFß1 signaling pathway can activate MMP7 expression and function directly or indirectly via LEF1 activation as previously reported $(43,47-49)$. Proteolytic degradation of E-cadherin at the cell surface by MMPs, such as MMP7 or -3 , appears to be another powerful and important mechanism for disassembly of the adheren junction by which E-cadherin-mediated cell-cell adhesion can be ablated. The major and common access for down-regulation of E-cadherin is known as transcriptional repression of E-cadherin-regulating genes, whereas the ubiquitination of E-cadherin with recruitment of Hakai, an E3 ubiquitin ligase, followed by endocytosis and lysosomal degradation is other mechanisms for the down-regulation of the molecule (50). Our present experiment, however, did not detect any remarkable expression of the mechanism-related genes (data not shown). As a result of the decrease in Ecadherin in the intracellular protein level, cytoplasmic-free (signaling) B-catenin may increase and translocate to the nuclei, resulting in further modulation of $\beta$-catenin/LEF1 target-gene expression $(33,51)$, such as Wnt pathway-mediated signaling. Overexpression of LEF1, one of the nuclear partners of $\beta$-catenin in the Wnt signaling pathway, in 3D-cultured tumor cells might be further potentiated by TGFß1/Smad2, 3 signaling and continuously down-regulate E-cadherin transcription $(33,35)$, since the LEF1 targeted the down-stream Slug gene (52). The LEF1 family also modulates expression of their target genes containing CD44 $(43,49)$, fibronectin (43), and MMP7. Furthermore, Wnt7A, a protein of Wnt/ B-catenin signaling, was up-regulated in the 3D-cultured A431 cells. Wnt7A has been reported to be a potent celltransforming protein (53) and may be one of the TGFß target genes such as Wnt5A (54). Slug up-regulation may be caused partly by Wnt signal activation, resulting in GSK-3ß inhibition $(21,55)$. It is also predictable that MMP7 overexpression is promoted directly not only by Wnt/LEF1 (47), but also by the FGF2/AP1/STAT1/3 (56) pathway. Further studies will be necessary to demonstrate a more detailed cross-talk mechanism between TGF/Smad and Wnt/ß-catenin signaling. Moreover, of particular interest was the observation that A431 squamous cell carcinoma cells cultured in the $3 \mathrm{D}$ system expressed the HMGA2 nuclear factor, which previously has only been expressed in mesenchymal cell types (57). In the 3D cultured cells, the TGF31/Smad signal activation attributed to not only leading to the overexpression of HMGA2 and its down-stream Slug, but also to the down-regulation of Id2, which were able to disturb the replacement and reconstitution of E-cadherin
$(34,37,58)$. Overexpression of HMGA2, which induces upregulation of the E-cadherin transcriptional suppressors, Snail, Slug, and Twist and down-regulation of Id2, results in E-cadherin suppression, followed by EMT progression. It is of interest in this study that both TGFß/Smad mediated activation of HMGA2 and TGFß1-induced MMPs, namely MMP7-dependent disassembly of E-cadherin, consequently induced overexpression of the transcriptional regulator, Slug. Additional up-regulation of $\mathrm{NF}-\kappa \mathrm{B}$, a key regulator for cell survival, acted synergistically with Smad signaling and promoted these phenomena because not only E-cadherinrepressors, Twist and Snail $(59,60)$, but also MMPs (59) have been demonstrated as transcriptional down-stream targets of $\mathrm{NF}-\kappa \mathrm{B}$. Additionally increased LOX family enzymes acted synergistically with Snail to down-regulate E-cadherin expression (61).

In the present study, increased expression of the HEY1, which relates not only to Notch signaling but also to the TGFß1 signaling pathway $(39,62)$, was observed. In A431 cells cultured in the RFB, Notch-ligand, Jagged-1, was also up-regulated as one of the TGFß1 target genes (62). Notchregulated transcriptional factor HEY1 function is required in the TGFß1-induced disassembly of E-cadherin adherens junctions, cell-cell separation and cell motility (39). The tumor cells cultured under RFB conditions demonstrated functional integration of the TGFß/Smad and Notch/Jagged-1 pathways cross talk, as TGFß induces the expression of both HEY1 and Jagged-1, leading to EMT in skin cancer progression, described previously $(26,29,39)$.

TGFß1/Smad2, 3 signaling pathways induced regulated expression of various molecules related to angiogenesis and invasiveness in 3D-cultured tumor cells. Elimination of the adhesion between surrounding cells or connective tissue to acquire a migratory phenotype is necessary for the epithelial cells as they must acquire metastatic motility, such as that of mesenchymal cells, in order to develop into tumor cells with EMT $(15,20,23)$. Many intercellular junctional proteins, Ecadherin in an adherens junction, ZO-1, occuludin, claudin and Par6 in a tight junction, E-cadherin, dysadherin, desmoplakin and desmogleins in a desmosomal junction, and their related cytokeratins, show fluctuations in either the mRNA or protein levels, leading to subsequent acquisition of the character of increased migration of epithelial cells. TGFß-stimulated Slug activation and Id2 suppression in this study may act in part in the desmosomal disassembly or tight and adherens junctional disorganization, because of their regulatory mechanisms $(21,32,34,35,37,57,58)$. In the present study, discrepancy between the intracellular increase in connexin26 mRNA and the decrease in the protein levels was recognized in 3D-cultured cells. It was considered that connexin26, a functional component of the gap junction, was located in the cytoplasm and did not traffic and reach the plasma membrane. As a result, the connexin 26 protein was degraded by proteasome because of rapid removal through mis-targeting as an unnecessary protein (63). It was likely that the elevated activity of proteasome in the tumor cells from $3 \mathrm{D}$ as compared with 2D culture, accelerated the connexin26 degradation. The supportive data were that mis-targeting followed by degradation of the connexin 26 protein resulted in decreased levels of cytokeratin 18 , which usually is up- 
regulated concomitantly with connexin26-overexpression (64). This tendency of the mRNA expression of connexin26 was recognized even in nude mouse tumor xenografts. There has been controversy on whether the overexpression of connexin26 in tumor cells is proportional to the increase in malignant potency as judged by the metastatic ability of the cells (64-66). The discrepancy between mRNA and protein expression cannot be fully explained at the present time, however, focal and patchy distribution of the connexin26 on cytoplasmic membranes and proteasomal over-function in the $3 \mathrm{D}$-cultured tumor cells provided informative suggestions and further analyses will be necessary to resolve this matter, because other regulatory (inhibitory) mechanisms may exist for connexin26 protein expression.

Simultaneously, the vast majority of proteolytic enzymes, such as MMPs, appeared to be increased as seen at either the mRNA or protein level, suggesting loss of the cell-matrix adhesion needed for remodeling and invasion in 3D-cultured cells. Under the 3D conditions, CD44 (hyaluronan receptor) and integrin [extracellular matrix (ECM) receptor], as the anchoring devices to ECM, and fibronectin, hyaluronan, collagen, and laminin as the scaffold of migration of the cells changed their expression levels or nature to promote cellular adhesion and migration much more than those proteins in normal tissues, showing the features of the malignant tumor phenotype $(3,8,13,14,67,68)$. Consequently, characteristics of the metastagenicity have strongly appeared in the 3D-cultured cells, relative to $2 \mathrm{D}$ cells. It is also interesting that hyaluronan has been known as a potent inducer of TGFß1 signaling after binding to cell surface CD44 $(20,69)$. The increased expression of these kinds of molecules, which were rarely detectable in 2D-cultured cells, is potent proof of the superiority of 3D cell culture using the RFB system for exhibiting the various characteristics and functions of the cells during the EMT process. These results demonstrated that even if the tumor cells were cultivated under 3D culture conditions without any experimental manipulations, they manifested a variety of phenotypes of motility, invasiveness and angiogenesis which were barely detectable in the 2D monolayer culture system. It has been believed that in general, the induction of EMT by TGFß is extremely difficult in cell lines in vitro $(1,2,8,32)$, although many reports have been documented. The RFB culture system seems to be a useful model for research and analysis of the onset and course of EMT. Since elimination of the unknown effect of factors, such as host animal-derived cytokines, on xenografted tumor cells is difficult to achieve with a conventional tumor model using human tumor cell xenotransplantation into the animal $(1,2,8,32)$, the importance of the $3 \mathrm{D}$ culture system is that it reduces unnecessary hostderived modifications of the transplanted tissues or cells. In the present study, this advantage explains the discrepancy and unexpected results among the mRNA expression of several kinds of genes, such as cytokines and their receptor groups, in the tumor cells obtained from nude mouse xenografts and from 3D- as well as 2D-cultured cells. By the design and setting of the experiments, careful analyses may be necessary.

The TGFß pathway is the key route of EMT and the major signaling activated by TGFß occurs via Smad pathways. However, non-Smad signaling containing mitogen-activated protein kinases and TGFß-activated kinase 1 pathways also participates in TGFß-signaling $(16,36,70)$. In the tumor cells cultured under 3D conditions, prolonged stabilization of hypoxia inducible factor 1 , another but master transcriptional regulator that plays important roles in tumor progression, invasion, and metastasis, was also found through the TGFß/ Smad signaling pathway, which inhibits the expression of prolyl hydroxylase 2 (71). Further investigations are now ongoing.

A431 squamous cell carcinoma culture by a 3D system in the RFB enabled induction of EMT features in tumor cells, similar to an animal transplantation microenvironment. However, whether or not 3D culture of various types of tumor cells achieves equivalent results remains uncertain. Tumor cell culture under the 3D microenvironment in the RFB overcomes the disadvantages of in vitro monolayer culture and closely mimics the in vivo environment.

\section{Acknowledgements}

This study was supported in part by Grant-in-Aids for Scientific Research from the Ministry of Education, Culture, Sports, Science and Technology and Ministry of Health, Labour and Welfare, Japan.

\section{References}

1. Debnath J and Brugge JS: Modelling glandular epithelial cancers in three-dimensional cultures. Nat Rev Cancer 5: 675-688, 2005.

2. Friedrich MJ: Studying cancer in 3 dimensions. 3-D models foster new insights into tumorigenesis. JAMA 18: 1977-1979, 2007.

3. Muthuswamy SK, Li D, Lelievre S, Bissell MJ and Brugge JS: ErbB2, but not ErbB1, reinitiates proliferation and induces luminal repopulation in epithelial acini. Nat Cell Biol 3: 785-792, 2001.

4. Ghosh S, Spagnoli GC, Martin I, Ploegert S, Demougin P, Heberer $M$ and Reschner A: Three-dimensional culture of melanoma cells profoundly affects gene expression profile: a high density oligonucleotide array study. J Cell Physiol 204: 522-531, 2005.

5. Hongo T, Kajikawa M, Ishida S, Ozawa S, Ohno Y, Sawada J, Ishikawa $\mathrm{Y}$ and Honda H: Gene expression property of highdensity three-dimensional tissue of HepG2 cells formed in radial-flow bioreactor. J Biosci Bioeng 101: 243-250, 2006.

6. Debnath J, Mills KR, Collins NL, Reginato MJ, Muthuswamy SK and Brugge JS: The role of apoptosis in creating and maintaining luminal space within normal and oncogene-expressing mammary acini. Cell 111: 29-40, 2002.

7. Weaver VM, Lelièvre S, Lakins JN, Chrenek MA, Jones JC, Giancotti F, Werb Z and Bissell MJ: Beta4 integrin-dependent formation of polarized three-dimensional architecture confers resistance to apoptosis in normal and malignant mammary epithelium. Cancer Cell 2: 205-216, 2002.

8. Nguyen DX and Massagué J: Genetic determinants of cancer metastasis. Nat Rev Genet 8: 341-352, 2007.

9. Aizaki H, Nagamori S, Matsuda M, Kawakami H, Hashimoto O, Ishiko H, Kawada M, Matsuura T, Hasumura S, Matsuura Y, Suzuki T and Miyamura T: Production and release of infectious hepatitis $\mathrm{C}$ virus from human liver cell cultures in the threedimensional radial-flow bioreactor. Virology 15: 16-25, 2003.

10. Kanai H, Marushima H, Kimura N, Iwaki T, Saito M, Maehashi H, Shimizu K, Muto M, Masaki T, Ohkawa K, Yokoyama K, Nakayama M, Harada T, Hano H, Hataba Y, Fukuda T, Nakamura M, Totsuka N, Ishikawa S, Unemura Y, Ishii Y, Yanaga $\mathrm{K}$ and Matsuura T: Extracorporeal bioartificial liver using the radial-flow bioreactor in treatment of fatal experimental hepatic encephalopat. Artif Organs 31: 148-151, 2007.

11. Kosuge M, Takizawa H, Maehashi H, Matsuura T and Matsufuji S: A comprehensive gene expression analysis of human hepatocellular carcinoma cell lines as components of a bioartificial liver using a radial flow bioreactor. Liver Int 27 : 101-108, 2007. 
12. Gupta PB, Kuperwasser C, Brunet JP, Ramaswamy S, Kuo WL, Gray JW, Naber SP and Weinberg RA: The melanocyte differentiation program predisposes to metastasis after neoplastic transformation. Nat Genet 37: 1047-1054, 2005.

13. Gupta GP and Massagué J: Cancer metastasis: building a framework. Cell 17: 679-695, 2006.

14. Janes SM and Watt FM: New roles for integrins in squamous-cell carcinoma. Nat Rev Cancer 6: 175-183, 2006.

15. Hay ED: An overview of epithelio-mesenchymal transformation. Acta Anat (Basel) 154: 8-20, 1995.

16. Huber MA, Kraut N and Beug H: Molecular requirements for epithelial-mesenchymal transition during tumor progression. Curr Opin Cell Biol 17: 548-558, 2005.

17. Hugo H, Ackland ML, Blick T, Lawrence MG, Clements JA, Williams ED and Thompson EW: Epithelial-mesenchymal and mesenchymal-epithelial transitions in carcinoma progression. J Cell Physiol 213: 374-383, 2007.

18. Lee JM, Dedhar S. Kalluri R and Thompson EW: The epithelialmesenchymal transition: new insights in signaling, development, and disease. J Cell Biol 172: 973-981, 2006.

19. Jechlinger M, Grunert S, Tamir IH, Janda E, Lüdemann S, Waerner T, Seither P, Weith A, Beug H and Kraut N: Expression profiling of epithelial plasticity in tumor progression. Oncogene 22: 7155-7169, 2003.

20. Pardali K and Moustakas A: Actions of TGF-beta as tumor suppressor and pro-metastatic factor in human cancer. Biochim Biophys Acta 1775: 21-62, 2007.

21. Zavadil J and Böttinger EP: TGF-beta and epithelial-tomesenchymal transitions. Oncogene 24: 5764-5774, 2005.

22. Tarin D, Thompson EW and Newgreen DF: The fallacy of epithelial mesenchymal transition in neoplasia. Cancer Res 65 5996-6000, 2005.

23. Leivonen SK and Kähäri VM: Transforming growth factor-beta signaling in cancer invasion and metastasis. Int $\mathrm{J}$ Cancer 121: 2119-2124, 2007.

24. Shariat SF, Shalev M, Menesses-Diaz A, Kim IY, Kattan MW, Wheeler TM and Slawin KM: Preoperative plasma levels of transforming growth factor beta(1) (TGF-beta(1)) strongly predict progression in patients undergoing radical prostatectomy. J Clin Oncol 19: 2856-2864, 2001

25. Tsushima H, Kawata S, Tamura S, Ito N, Shirai Y, Kiso S, Imai Y, Shimomukai H, Nomura $Y$, Matsuda $Y$ and Matsuzawa Y: High levels of transforming growth factor beta 1 in patients with colorectal cancer: association with disease progression. Gastroenterology 110: 375-382, 1996.

26. Cui W, Fowlis DJ, Bryson S, Duffie E, Ireland H, Balmain A and Akhurst RJ: TGFbeta1 inhibits the formation of benign skin tumors, but enhances progression to invasive spindle carcinomas in transgenic mice. Cell 86: 531-542, 1996.

27. Han G, Lu SL, Li AG, He W, Corless CL, Kulesz-Martin M and Wang XJ: Distinct mechanisms of TGF-beta1-mediated epithelial-to-mesenchymal transition and metastasis during skin carcinogenesis. J Clin Invest 115: 1714-1723, 2005.

28. Rees JRE, Onwuegbusi BA, Save VE, Alderson D and Fitzgerald RC: In vivo and in vitro evidence for transforming growth factor- $\$ 1$-mediated epithelial to mesenchymal transition in esophageal adenocarcinoma. Cancer Res 66: 9583-9590, 2006.

29. Weijzen S, Rizzo P, Braid M, Vaishnav R, Jonkheer SM, Zlobin A, Osborne BA, Gottipati S, Aster JC, Hahn WC, Rudolf M, Siziopikou K, Kast WM and Miele L: Activation of Notch-1 signaling maintains the neoplastic phenotype in human Ras-transformed cells. Nat Med 8: 979-986, 2002

30. Fransvea E, Angelotti U, Antonaci S and Giannelli G: Blocking transforming growth factor-beta up-regulates E-cadherin and reduces migration and invasion of hepatocellular carcinoma cells. Hepatology 47: 1557-1566, 2008.

31. Giannelli G, Bergamini C, Fransvea E, Sgarra C and Antonaci S: Laminin-5 with transforming growth factor-beta 1 induces epithelial to mesenchymal transition in hepatocellular carcinoma. Gastroenterology 129: 1375-1383, 2005.

32. Ahmed S and Nawshad A: Complexity in interpretation of embryonic epithelial-mesenchymal transition in response to transforming growth factor-beta signaling. Cells Tissues Organs 185: 131-145, 2007

33. Eger A, Stockinger A, Park J, Langkopf E, Mikula M, Gotzmann J, Mikulits W, Beug H and Foisner R: beta-Catenin and TGFbeta signalling cooperate to maintain a mesenchymal phenotype after FosER-induced epithelial to mesenchymal transition. Oncogene 23: 2672-2680, 2004.
34. Kondo M, Cubillo E, Tobiume K, Shirakihara T, Fukuda N, Suzuki H, Shimizu K, Takehara K, Cano A, Saitoh M and Miyazono K: A role for Id in the regulation of TGF-beta-induced epithelial-mesenchymal transdifferentiation. Cell Death Differ 11: 1092-1101, 2004.

35. Medici D, Hay ED and Goodenough DA: Cooperation between snail and LEF-1 transcription factors is essential for TGF-beta1induced epithelial-mesenchymal transition. Mol Biol Cell 17: 1871-1879, 2006.

36. Moustakas A and Heldin CH: Non-Smad TGF-beta signals. J Cell Sci 118: 3573-3584, 2005.

37. Valcourt U, Kowanetz M, Niimi H, Heldin CH and Moustakas A: TGF-beta and the Smad signaling pathway support transcriptomic reprogramming during epithelial-mesenchymal cell transition. Mol Biol Cell 16: 1987-2002, 2005.

38. Zavadil J, Bitzer M, Liang D, Yang Y-C, Massimi A, Kneitz S, Piek E and Böttinger EP: Genetic programs of epithelial cell plasticity directed by transforming growth factor- $\beta$. Proc Natl Acad Sci USA 98: 6686-6691, 2001.

39. Zavadil J, Cermak L, Soto-Nieves N and Böttinger EP: Integration of TGF-beta/Smad and Jagged1/Notch signalling in epithelial-to-mesenchymal transition. EMBO J 23: 1155-1165, 2004.

40. Nawshad A, Medici D, Liu CC and Hay ED: TGFbeta3 inhibits E-cadherin gene expression in palate medial-edge epithelial cells through a Smad2-Smad4-LEF1 transcription complex. J Cell Sci 120: 1646-1653, 2007

41. Peinado H, Olmeda D and Cano A: Snail, Zeb and bHLH factors in tumour progression: an alliance against the epithelial phenotype? Nat Rev Cancer 7: 415-428, 2007.

42. Stemmer V, de Craene B, Berx G and Behrens J: Snail promotes Wnt target gene expression and interacts with $\beta$-catenin. Oncogene 27: 5075-5080, 2008

43. Cavallaro U and Christofori G: Cell adhesion and signalling by cadherins and Ig-CAMs in cancer. Nat Rev Cancer 4: 118-132, 2004.

44. Wang F, Reierstad S and Fishman DA: Matrilysin over-expression in MCF-7 cells enhances cellular invasiveness and pro-gelatinase activation. Cancer Lett 236: 292-301, 2006.

45. Shiomi T and Okada Y: MT1-MMP and MMP-7 in invasion and metastasis of human cancers. Cancer Metastasis Rev 22: $145-152,2003$

46. Wever ODe, Derycke L, Hendrix A, De Meerleer G, Godeau F, Depypere H and Bracke M: Soluble cadherins as cancer biomarkers. Clin Exp Metastasis 24: 685-697, 2007.

47. Jovanovic V, Dugast AS, Heslan JM, Ashton-Chess J, Giral M, Degauque N, Moreau A, Pallier A, Chiffoleau E, Lair D, Usal C, Smit H, Vanhove B, Soulillou JP and Brouard S: Implication of matrix metalloproteinase 7 and the noncanonical wingless-type signaling pathway in a model of kidney allograft tolerance induced by the administration of anti-donor class II antibodies. J Immunol 180: 1317-1325, 2008.

48. Osteen KG, Keller NR, Feltus FA and Melner MH: Paracrine regulation of matrix metalloproteinase expression in the normal human endometrium. Gynecol Obstet Invest 48 (Suppl 1): 2-13, 1999.

49. Wong NA and Pignatelli M: Beta-catenin - a linchpin in colorectal carcinogenesis? Am J Pathol 160: 389-401, 2002.

50. Fujita Y, Krause G, Scheffner M, Zechner D, Leddy HE, Behrens J, Sommer T and Birchmeier W: Hakai, a c-Cbl-like protein, ubiquitinates and induces endocytosis of the E-cadherin complex. Nat Cell Biol 4: 222-231, 2002.

51. Nelson WJ and Nusse R: Convergence of Wnt, beta-catenin, and cadherin pathways. Science 303: 1483-1487, 2004.

52. Conacci-Sorrell M, Simcha I, Ben-Yedidia T, Blechman J, Savagner P and Ben-Ze'ev A: Autoregulation of E-cadherin expression by cadherin-cadherin interactions: the roles of betacatenin signaling, Slug, and MAPK. J Cell Biol 163: 847-857, 2003.

53. Wong GT, Gavin BJ and McMahon AP: Differential transformation of mammary epithelial cells by Wnt genes. Mol Cell Biol 14: 6278-6286, 1994.

54. Ripka S, König A, Buchholz M, Wagner M, Sipos B, Klöppel G, Downward J, Gress T and Michl P: WNT5A-target of CUTL1 and potent modulator of tumor cell migration and invasion in pancreatic cancer. Carcinogenesis 28: 1178-1187, 2007.

55. Bachelder RE, Yoon S-O, Franci C, de Herreros AG and Mercurio AM: Glycogen synthase kinase-3 is an endogenous inhibitor of Snail transcription: implications for the epithelialmesenchymal transition. J Cell Biol 168: 29-33, 2005. 
56. Holnthoner W, Kerenyi M, Gröger M, Kratochvill F and Petzelbauer P: Regulation of matrilysin expression in endothelium by fibroblast growth factor-2. Biochem Biophys Res Commun 342: 725-733, 2006.

57. Thuault S, Valcourt U, Petersen M, Manfioletti G, Heldin $\mathrm{CH}$ and Moustakas A: Transforming growth factor- $\beta$ employs HMGA2 to elicit epithelial-mesenchymal transition. J Cell Biol 174: 175-183, 2006.

58. Kowanetz M, Valcourt U, Bergström R, Heldin CH and Moustakas A: Id 2 and Id 3 define the potency of cell proliferation and differentiation responses to transforming growth factor beta and bone morphogenetic protein. Mol Cell Biol 24: 4241-4254, 2004.

59. Huber MA, Azoitei N, Baumann B, Grünert S, Sommer A, Pehamberger H, Kraut N, Beug H and Wirth T: NF-kappaB is essential for epithelial-mesenchymal transition and metastasis in a model of breast cancer progression. J Clin Invest 114: 569-581, 2004.

60. Kang Y and Massagué J: Epithelial-mesenchymal transitions: twist in development and metastasis. Cell 118: 277-279, 2004

61. Peinado H, de la Cruz MCI, Olmeda D, Csiszar K, Fong KSK Vega S, Nieto MA, Cano A and Portillo F: A molecular role for lysyl oxidase-like 2 enzyme in snail regulation and tumor progression. EMBO J 24: 3446-3458, 2005.

62. Niimi H, Pardali K, Vanlandewijck M, Heldin $\mathrm{CH}$ and Moustakas A: Notch signaling is necessary for epithelial growth arrest by TGF-beta. J Cell Biol 176: 695-707, 2007.

63. Leithe $\mathrm{E}$ and Rivedal E: Ubiquitination of gap junction proteins. J Membr Biol 217: 43-51, 2007.

64. McLachlan E, Shao Q, Wang HL, Langlois S and Laird DW: Connexins act as tumor suppressors in three-dimensional mammary cell organoids by regulating differentiation and angiogenesis. Cancer Res 66: 9886-9894, 2006.
65. Ito A, Koma Y, Uchino K, Okada T, Ohbayashi C, Tsubota N and Okada M: Increased expression of connexin 26 in the invasive component of lung squamous cell carcinoma: significant correlation with poor prognosis. Cancer Lett 234: 239-248, 2006.

66. Lee HJ, Lee IK, Seul KH and Rhee SK: Growth inhibition by connexin 26 expression in cultured rodent tumor cells. Mol Cells 14: 136-142, 2002.

67. Davis GE and Senger DR: Endothelial extracellular matrix: biosynthesis, remodeling, and functions during vascular morphogenesis and neovessel stabilization. Circ Res 97: 1093-1107, 2005.

68. Miyazaki K: Laminin-5 (laminin-332): Unique biological activity and role in tumor growth and invasion. Cancer Sci 97: 91-98, 2006

69. Bourguignon LY, Singleton PA, Zhu H and Zhou B: Hyaluronan promotes signaling interaction between CD44 and the transforming growth factor beta receptor I in metastatic breast tumor cells. J Biol Chem 277: 39703-39712, 2002.

70. Alcorn JF, Guala AS, van der Velden J, McElhinney B, Irvin CG, Davis RJ and Janssen-Heininger YM: Jun N-terminal kinase 1 regulates epithelial-to-mesenchymal transition induced by TGFbeta1. J Cell Sci 121: 1036-1045, 2008.

71. McMahon S, Charbonneau M, Grandmont S, Richard DE and Dubois CM: Transforming growth factor beta 1 induces hypoxia-inducible factor-1 stabilization through selective inhibition of PHD2 expression. J Biol Chem 281: 24171-24181, 2006. 